\begin{tabular}{|c|c|c|c|c|c|c|}
\hline \multirow{4}{*}{ Impact Factor: } & ISRA (India) & $=3.117$ & SIS (USA) & $=0.912$ & ICV (Poland) & $=6.630$ \\
\hline & ISI (Dubai, UAE & $=0.829$ & РИНЦ (Russia) & $=0.156$ & PIF (India) & $=1.940$ \\
\hline & GIF (Australia) & $=0.564$ & ESJI (KZ) & $=8.716$ & IBI (India) & $=4.260$ \\
\hline & JIF & $=1.500$ & SJIF (Morocco) & $=5.667$ & OAJI (USA) & $=0.350$ \\
\hline
\end{tabular}

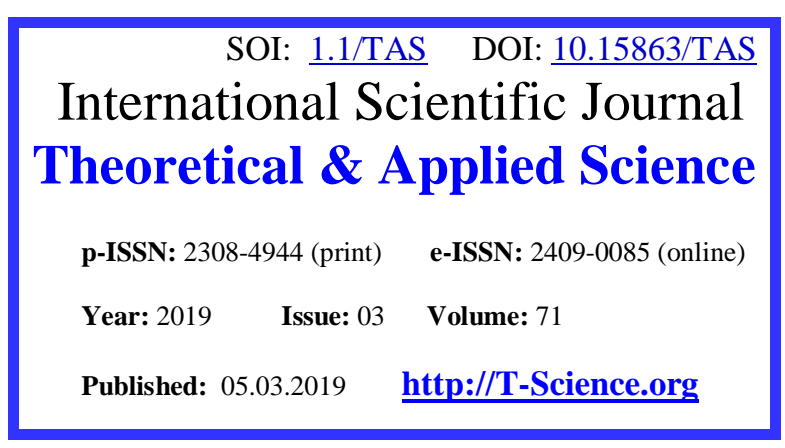

UDC 335. 47 519. 74.

SECTION: TECHNICAL SCIENCES
QR - Issue

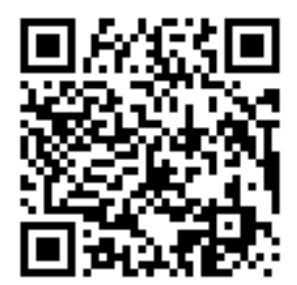

Artur Alexandrovich Blagorodov bachelor,

Department of "Design, technology, and design" Institute of service sector and entrepreneurship (branch) of DSTU in Shakhty, Rostov region bordux1995@icloud.com

\section{Dmitry Olegovich Bordukh} bachelor,

Department of "Design, technology, and design" Institute of service sector and entrepreneurship (branch) of DSTU in Shakhty, Rostov region bordux1995@icloud.com

Angelina Vladimirovna Kopylova bachelor,

Department of "Design, technology, and design" Institute of service sector and entrepreneurship (branch) of DSTU in Shakhty, Rostov region prohorov@sssu.ru

Daria Sergeevna Smolina bachelor,

Department of "Design, technology, and design" Institute of service sector and entrepreneurship (branch) of DSTU in Shakhty, Rostov region prohorov@sssu.ru

Vladimir Timofeevich Prokhorov Doctor of technical sciences, professor, the department "Designing, technology and design", ISOP

(f) DGTU, Shakhty prohorov@sssu.ru

Yuri Dmitrievich Mishin candidate of philosophy, Professor, Department of Philosophy and Culturology "Siberian state University of railway communication" Novosibirsk vinichenkoan@stu.ru

\title{
METHODOLOGICAL BASES OF QUALITY MANAGEMENT OF DIGITAL PRODUCTION OF DEFECT-FREE AND IMPORT- SUBSTITUTING TRUE FOR USERS OF THE SFD AND SKFO (3 MESSAGE)
}

Abstract: In report 3, the authors analyze the possibilities of policy and objectives of the company in the field of quality within the QMS in order to fight for defect-free production, reduction of marriage and guarantees consumers high quality of manufactured products. The use of Pareto charts allowed us to visualize the efficiency and 


\begin{tabular}{|c|c|c|c|c|c|c|}
\hline \multirow{4}{*}{ Imp } & ISRA (India) & 3.117 & SIS (USA) & $=0.912$ & ICV (Poland) & $=6.630$ \\
\hline & ISI (Dubai, UAE & $=0.829$ & РИНЦ (Russia & 0.156 & PIF (India) & 940 \\
\hline & GIF (Australia) & $=0.564$ & ESJI (KZ) & $=8.716$ & IBI (India) & $=4.260$ \\
\hline & JIF & $=1.50$ & SJIF $($ Mor & -5667 & OAJI (USA) & $=0.350$ \\
\hline
\end{tabular}

effectiveness developed by the authors of the policies and objectives in the field of quality within the QMS to ensure defect-free production with a substantial decrease in the production of defective products. The need to improve the quality management system in the light industry is due to the following important reasons. First, it is increasing the confidence of potential consumers in the products that the company produces. Secondly, it is an opportunity to significantly strengthen its position in existing markets, as well as significantly expand its sphere of influence by entering new domestic and foreign markets. And thirdly - it is a significant increase in productivity of any industrial enterprise which is supposed to introduce QMS using participatory management.

Key words: QMS, certification, import substitution, demanded, conformity assessment, standardization, audit, demand, defective products, Pareto chart, quality policy and objectives, documentation, effectiveness, efficiency, responsibility.

Language: Russian

Citation: Blagorodov, A. A., Bordukh, D. O., Kopylova, A. V., Smolina, D. S., Prokhorov, V. T., \& Mishin, Y. D. (2019). Methodological bases of quality management of digital production of defect-free and import-substituting true for users of the SFD and SKFO (3 message). ISJ Theoretical \& Applied Science, 03 (71), 146-183.

Soi: http://s-o-i.org/1.1/TAS-03-71-15 Doi: crossef https://dx.doi.org/10.15863/TAS.2019.03.71.15

\section{МЕТОДОЛОГИЧЕСКИЕ ОСНОВЫ УПРАВЛЕНИЯ КАЧЕСТВОМ ЦИФРОВОГО ПРОИЗВОДСТВА БЕЗДЕФЕКТНОЙ И ИМПОРТОЗАМЕЩАЕМОЙ ПРОДУЦИИ ДЛЯ ПОТРЕБИТЕЛЕЙ ЮФО И СКФО (СООБЩЕНИЕ 3)}

Аннотация: в сообщении 3 авторы анализируют возможности политики и иели предприятия 6 области качества в рамках СМК для того, чтобы бороться за бездефектное производство, снижение брака и гарантирует потребителям высокое качество изготавливаемой продукции. Использование диаграммы Парето позволили наглядно представить эффективность и результативность разработанной авторами политики и иелей в области качества в рамках СМК для обеспечения бездефектного производства с существенным снижением выпуска бракованной продукции. Необходимость совершенствования системы менеджмента качества на предприятиях легкой промышленности обусловлено следующими важными причинами. Во-первых, это повышение доверия потенцииальных потребителей к продукции, которую выпускает данное предприятие. Во-вторых, это возможность значительно укрепить свое положение на уже существуюших рынках, а также значительно расширить сферы влияния путем выхода на новые отечественные и зарубежные рынки. И в-третьих - это значительное повышение производительности труда любого промышленного предприятия на котором предполагается внедрение СМК с использованием партисипативного управления.

Ключевые слова: СМК, сертификация, импортозамещение, востребованное, подтверждение соответствия, стандартизация, аудит, спрос, бракованная продукция, диаграмма Парето, политика и цели качества, документация, результативность, эффективность, ответственность.

\section{Введение}

Начинать классически исследование приходится характеристики проблемы. Удивительно, но тем не менее, факт, что несмотря на многочисленную литературу по предлагаемой теме и не менее четкие заявки на ее комплексный анализ, проблема комплексного исследования управления качеством остается «ежиком» в густом тумане.

Причина простая, за исключением работы Б.С. Алешина с соавторами, обещание комплексного изучения проблемы остается пожеланием. Содержание исследований обычно не выходит за рамки одного-двух аспектов рассмотрения качества и возможности управления качеством. Остальные ракурсы либо декларируются, либо прилагаются в настолько секвестрированном состоянии, что их присутствие воспринимается, как своего рода нагрузка за удовольствие приобщиться к авторским рассуждениям на, безусловно, актуальную на все времена и для любой деятельности тему [1-2].

Отмеченный недостаток присущ и нашим работам, посвященным проблеме качества. Нас извиняет в какой-то мере лишь то, что мы до сих пор избегали делать заявку на комплексное исследование качества в контексте управления. Вполне возможна и даже прогнозируема жесткая реакция наших критиков. Другие - и мы с ними, учтя критику, шагнут дальше, вперед, коллективно решая то, что не под силу отдельным исследователям, даже в том случае, когда они сочетают свои различные познавательные ресурсы и когда, как например, в нашем случае собираются вместе отраслевой специалист, экономист-системщик и философ.

Философский аспект.

В основе теории управления качеством лежит философская разработка этого понятия. «Качество» - философская категория и от того, насколько в теории управления качеством представлена философская составная, зависит 


\begin{tabular}{|c|c|c|c|c|c|c|}
\hline \multirow{4}{*}{ Impact Factor: } & ISRA (India) & $=3.117$ & SIS (USA) & $=0.912$ & ICV (Poland) & $=6.630$ \\
\hline & ISI (Dubai, UAE & $=0.829$ & РИНЦ (Russia & $=0.156$ & PIF (India) & $=1.940$ \\
\hline & GIF (Australia) & $=0.564$ & ESJI (KZ) & $=8.716$ & IBI (India) & $=4.260$ \\
\hline & JIF & $=1.500$ & SJIF (Morocco & $=5.667$ & OAJI (USA) & $=0.350$ \\
\hline
\end{tabular}

решение выдвинутой задачи. В философии же единого толкования качества никогда не было, нет взаимопонимания и в наше время. Отсюда следует важный вывод: надо, прежде чем выстраивать стратегию управления качеством, определиться, на какой философский «берег» вы собираетесь десантироваться.

Качество - общая и достаточно устойчивая определенность предметного множества. Стабильнее качества разве только формы бытия и его субстанция - единственное, что неизменно по определению. Качество, тем не менее, тоже течет по реке времени и меняется. Изменяется качество внутри себя, сменяя свои состояния, и радикально, теряя свою определенность, превращается в другое качество.

Различия в философском понимании качества обусловлены сложностью качества как предмета исследования, но еще в большей степени они - следствие философского миропонимания и методологии, на которой оно сформировано.

«Материализм», «идеализм», «метафизика», «диалектика»- изрядно потрепанные классовой идеологией философские понятия. Философы консерваторы в советское время неплохо устроились, возведя баррикады, из-за которых пускали стрелы гнева в своих врагов, абсолютизируя политическую подоплеку философских течений. Не в лучшем свете выглядят и торжествующие в объятиях либеральной демократии критики, расправляющиеся с неугомонным наследством. Воодушевленные «благородным гневом», они по существу повернулись в прошлое и не столько «топчут» это ненавистное прошлое, сколько топчутся на месте, тормозя движение познавательного процесса.

От «материализма», «идеализма», «метафизики», «диалектики» надо не отказываться, а их необходимо очистить от псевдо идеологической «шелухи», раскрыв тем самым заложенный рациональный смысл в данные явления. Эти понятия - своего рода «пограничные столбы» философского и научного познания, предупреждающие, с одной стороны, о необходимости придерживаться в познании некоторых ориентиров, с другой - требующие разработки условий пограничного взаимодействия.

Границы в познании призваны не отграничивать, изолировать одно от другого. Их разумность заключается в том, что они регламентируют познавательный процесс. К. Маркс, писавший, что идеализм Г. Гегеля есть «поставленный на голову материализм», не несет ответственность за своих последователей, упростивших марксизм и, в частности, философию марксизма - диалектический материализм.
Идеалист Г. Гегель равным образом не виноват, что Э. Мах довел идеалистическую идею до солипсизма, и своими философскими экзерсисами нанес ущерб рациональности, присущей высшим достижениям идеалистической философии.

История философии предупреждает всякого, кто вступил на путь познания: больше всего бойся односторонности. Она неизбежно ведет к абсолютизации, состоянию познания, при котором разрывается естественная связь в нем идеального и материального, закрывается движение к истине.

Управление качеством начинается с философской, то есть мировоззренческой и методологической ориентации теории. Никаких альтернативных вариантов нет. В разработке теории управления бессмысленно уклоняться от философских основ. Необходимо активно искать сотрудничества с философией, рационально истолкованной.

Вопрос: где она, эта рациональная философия, - давно стал риторическим, со времен первых философов. Ее в готовом виде не было, нет, и не будет как «палочки-выручалочки», «скатерти-самобранки», «философского камня».

Рационально истолкованная философия эксклюзивный продукт взаимодействия профессионального мышления с философским наследием. Возражения типа «не каждому по силам такое» вполне подходит к ситуации. Верно, такое дано всем, но и не все берут на себя ответственность строительства системы управления качеством. Большинство пребывает в ожидании указаний и нормативных материалов в полной комплектации. По нынешней моде: портфель с документами.

Наш российский рынок не только уродливо разорвал национальную экономику, одним подарив жирные куски, другим оставил призрачную надежду, что когда-нибудь их постная жизнь изменится и на их улицу придет праздник. Российский рынок лишил нас национального единства, обесценив то, что широко известно как «загадочная русская душа», a попросту говоря, свойственную нам тягу к размышлению «за жизнь вообще», включая сюда проблемы личные и национальные. Немца отличает законопослушание, американца из США - авантюризм, итальянца непосредственность. Наших предков выделяла ответственность, угасающая на глазах.

Философия качества - понятие собирательное, синтетически выстроенное. Понимание качества в различных философских теориях различаются существенно, ибо оно «подогнано» под систему и метод, использованный в ее разработке.

В подобной неоднозначной ситуации начинать надо с заключения: все правы и никто 


\begin{tabular}{|c|c|c|c|c|c|c|}
\hline \multirow{4}{*}{ Impact Factor: } & ISRA (India) & $=3.117$ & SIS (USA) & $=0.912$ & ICV (Poland) & $=6.630$ \\
\hline & ISI (Dubai, UAE & $=0.829$ & РИНЦ (Russia & $=0.156$ & PIF (India) & $=1.940$ \\
\hline & GIF (Australia) & $=0.564$ & ESJI (KZ) & $=8.716$ & IBI (India) & $=4.260$ \\
\hline & JIF & $=1.500$ & SJIF (Morocco & $=5.667$ & OAJI (USA) & $=0.350$ \\
\hline
\end{tabular}

неправ. Что за абракадабра, - скажет привыкший мыслить согласно заложенной природой формуле «или - или», - Нам не нужны загадки, мы хотим, чтобы все было по принципу: «каждому свое». Задача как раз и состоит в том, чтобы все разложить «по полочкам». Так проще, понятнее, не ошибешься.

Формальная логика мышления, складывается стихийно, отражает мир вещей в первом приближении, грубо. Ф. Энгельс ее справедливо сравнивал с элементарной математикой, которая не способна описывать процесс, поэтому ограничена действиями с конечными величинами. «Что такое хорошо и что такое плохо»- удел формальнологических рассуждений, для которых «нет худа без добра», или «две разных стороны одной медали»суждения не по правилам, запретные.

Запреты мышлению вводит и политическая идеология, разделяя мысли на свои и враждебные, правильные и неправильные, заставляя общественное сознание работать по упрощенным правилам формальной логики индивидуального мышления.

В марксисткой и гегелевской концепциях качества больше общего, чем отличий. Главное же то, что самое существенное в понимании качества совпадает. К. Маркс и Ф. Энгельс, дистанцируясь от гегелевского идеализма, всемерно оберегали его диалектическое понимание мышления, развивали выдвинутые им положения, защищали их от критики. Они лучше кого-либо сознавали резерв, заложенный в гегелевской диалектике познания.[3-4]

Качество и для Гегеля и для основоположников диалектического материализма, творивших после Гегеля, было:

- во-первых, совокупностью определенным образом связанных существенных свойств явлений;

- во-вторых, качество они понимали как объективное состояние, даже в том случае, когда оно создается сознанием человека, так как сознание творит качество согласно объективному порядку мира. Качество инвариантно объективно;

- в-третьих, в их понимании, качество изменяется в соответствии с диалектикой развития мира. Оно имеет конкретноисторический способ выражения.

Все три приведенных характеристики качества образуют методологический каркас: теории качества и стратегии управления качеством.

Свой вклад в философию качества внес и знаменитый предшественник Г. Гегеля, английский философ Дж. Локк. Дж. Локк разделил качество на две группы: объективные качества вещей, присущие им значительно, и качества, возникающие в процессе познания. Последние отсутствуют в вещах, но образуются при взаимодействии вещей и чувств человека. Вещи возбуждают определенные чувства и те реагируют образованием соответствующих полученным сигналом качеств - ощущений. Теорию двойственности качества Локка не критиковали только самые ленивые. Ему досталось от материалистов за уступки идеализму: не пощадили его и идеалисты за группу объективных качеств.

Означает столь активная критика убеждений английского мыслителя, что он во всем был не прав, заблудившись в дебрях философии качества? Отнюдь. Идеи умного человека не могут быть глупыми, если они не шутка, а Локк не шутил.

Философ пытался отыскать решение противоречий в развитии учения о качестве. Его не удовлетворял взгляд на качество ни упрощенного материализма, ни субъективных идеалистов, суждения которых вели в тупик.

Локк был далек от того, чтобы соединить идеи противников, и таким примитивным приемом преодолеть сложившийся конфликт. ОН хотел подчеркнуть роль сознания в истории формирования качества, активность субъекта, но не смог последовательно осуществить свой замысел. Заслуживает особого внимания суть его инициативы - стремления включить в теорию качества деятельность субъекта.

Прошло время, идея вызрела под действием практических факторов. Философы вернулись, нет ни к философии Локка, к его идее активности субъекта и роли его деятельность в формировании качества вещей. Не говоря о том, что актуальной стала и проблема своеобразия качества самой деятельности, создающей качество вещей.[5-6]

Достаточно вспомнить современную, международную систему контроля качества ИСО9001. Базовой в ней является именно идея качества деятельности. Качество и вещь ошибочно было бы отождествлять. Как особая комбинация свойств, качество, по определению, не то же самое, что вещь. Г. Гегель определял качество явления просто и в пределах философского понимания, которое в условиях рыночных отношений стыкуется с потребительской оценкой, понятию: «качество есть то, лишаясь чего, предмет перестает быть собою». «Перестает быть собою», однако не перестает существовать вообще.

Не отвечая требованиям качества, явление превращается из одного состояния в другое, либо в другое явление. Экспертиза дала заключение о несоответствии товара техническим (и потребительским) параметрам. Товар перевели в разряд не кондиции, бракованного изделия, но вещь осталась и вместе с ней сохранилась какаято перспектива ее утилизации: устранения несоответствия стандарту, переработка. Нельзя обувь носить, можно попробовать вычерпывать ею воду из протекающей лодки, трамбовать паклю, ботать, да мало ли на что несостоявшийся 


\begin{tabular}{|c|c|c|c|c|c|c|}
\hline \multirow{4}{*}{ Impact Factor: } & ISRA (India) & $=3.117$ & SIS (USA) & $=0.912$ & ICV (Poland) & $=6.630$ \\
\hline & ISI (Dubai, UAE & $=0.829$ & РИНЦ (Russia & $=0.156$ & PIF (India) & $=1.940$ \\
\hline & GIF (Australia) & $=0.564$ & ESJI (KZ) & $=8.716$ & IBI (India) & $=4.260$ \\
\hline & JIF & $=1.500$ & SJIF (Morocco & $=5.667$ & OAJI (USA) & $=0.350$ \\
\hline
\end{tabular}

сапог может сгодиться в большом хозяйстве, даже на самовар можно надеть.

Качество ошибочно отрывать от предмета не только с философской позиции, но и с точки зрения нефилософского осмысления, иначе качество превратится в нечто самостоятельное, подобно «Носу» из повести Н.В. Гоголя, и управление качеством потеряет предметную определенность. Ф. Энгельс подчеркивал: «Существуют не качества, а только вещи, обладающие качеством, и притом бесконечно многими качествами».

Специалисты отличают сдвиг потребностей на рынке в сторону качественных изделий. Рынок созревает. Это подтверждает мониторинг спроса. В данной долгожданной ситуации важно не потерять философскую почву, разрабатывая бизнес-план, согласно новым обстоятельствам.

Качество - это высшая и перманентная цель одновременно, поэтому нужно одно иметь на перспективу, а другому придать сегодняшний образ. Только правильная ориентация в конкретном времени как жизненном интервале, когда это именно актуально, гарантирует успех реализации товара.

Производитель и продавец должны быть современными. Их современность обусловлена способностью найти оптимальный товарный ассортимент и состыковать конкретный товар с ожидаемым уровнем качества, чтобы попасть в оптимальный ценовой диапазон, продиктованный платежеспособным спросом потребителя продукции, выражающим его потребность в товаре.

Качество для потребителя - не абстракция, созданная профессиональным мышлением производителя. Потребитель смотрит на качество через прицел кошелька. Пока существует рынок, цена остается его визитной карточкой. Если покупатель сначала просит показать товар и только потом спрашивает, сколько он стоит, то от перестановки элементов результат не меняется. Свой сакраментальный вопрос, от ответа на который будет зависеть, как разрешится акт купли-продажи, клиент задаст обязательно.

Качество к самостоятельному существованию не приспособлено. В качестве представлена вещь, когда она оказывается на рынке - товар. И вот здесь начинается главное в теории качества, поэтому остановимся и разберем проблему поподробнее.

Качество вещей, образующих природу, возникло естественно, стихийно, согласно сложному сочетанию природных закономерностей. Отсюда следует, что качество таких, естественным путем созданных явлений, однозначно объективно во всех отношениях.

Иной оказывается история качества явлений, созданных человеческой деятельностью. В общественной практике реализуется духовная составная человека. Человек строит дом, шьет обувь, одежду, согласуя свои действия с механическими, физическими, химическими, биологическими свойствами природных вещей, но делаем мы конечный продукт не для природы частные случаи опустим. Мы в создаваемой вещи, ее свойствах, в ее качестве реализуем свои цели, потребности, интересы: либо материализуем, либо объективируем. Различия объективности качества естественного явления и созданного человека приведены на рисунок 1 . 


\begin{tabular}{|c|c|c|c|c|c|c|}
\hline \multirow{4}{*}{ Impact Factor: } & ISRA (India) & $=\mathbf{3 . 1 1 7}$ & SIS (USA) & $=0.912$ & ICV (Poland) & $=6.630$ \\
\hline & ISI (Dubai, UAE & $=0.829$ & РИНЦ (Russia & $=0.156$ & PIF (India) & $=1.940$ \\
\hline & GIF (Australia) & $=0.564$ & ESJI (KZ) & $=8.716$ & IBI (India) & $=4.260$ \\
\hline & JIF & $=1.500$ & SJIF (Morocce & $=5.667$ & OAJI (USA) & $=0.350$ \\
\hline
\end{tabular}

качество

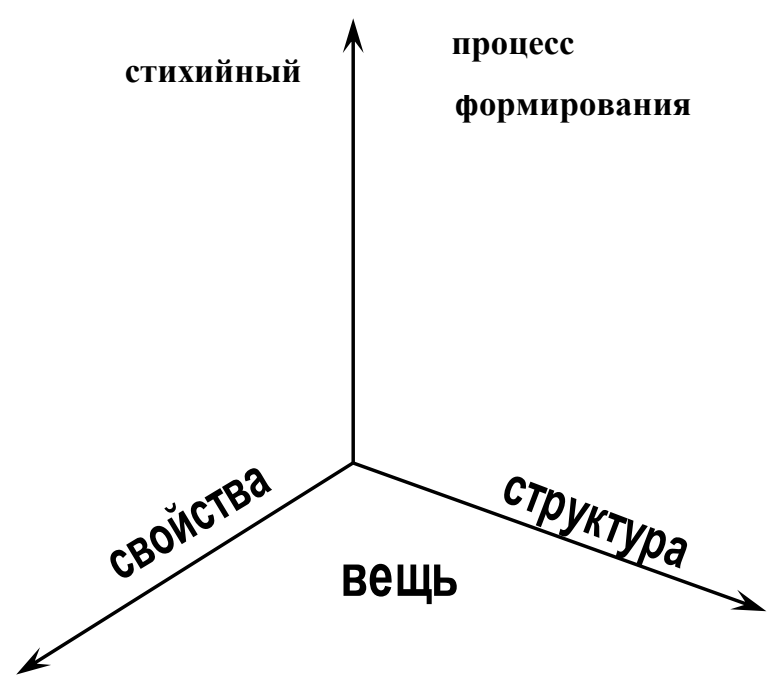

качество

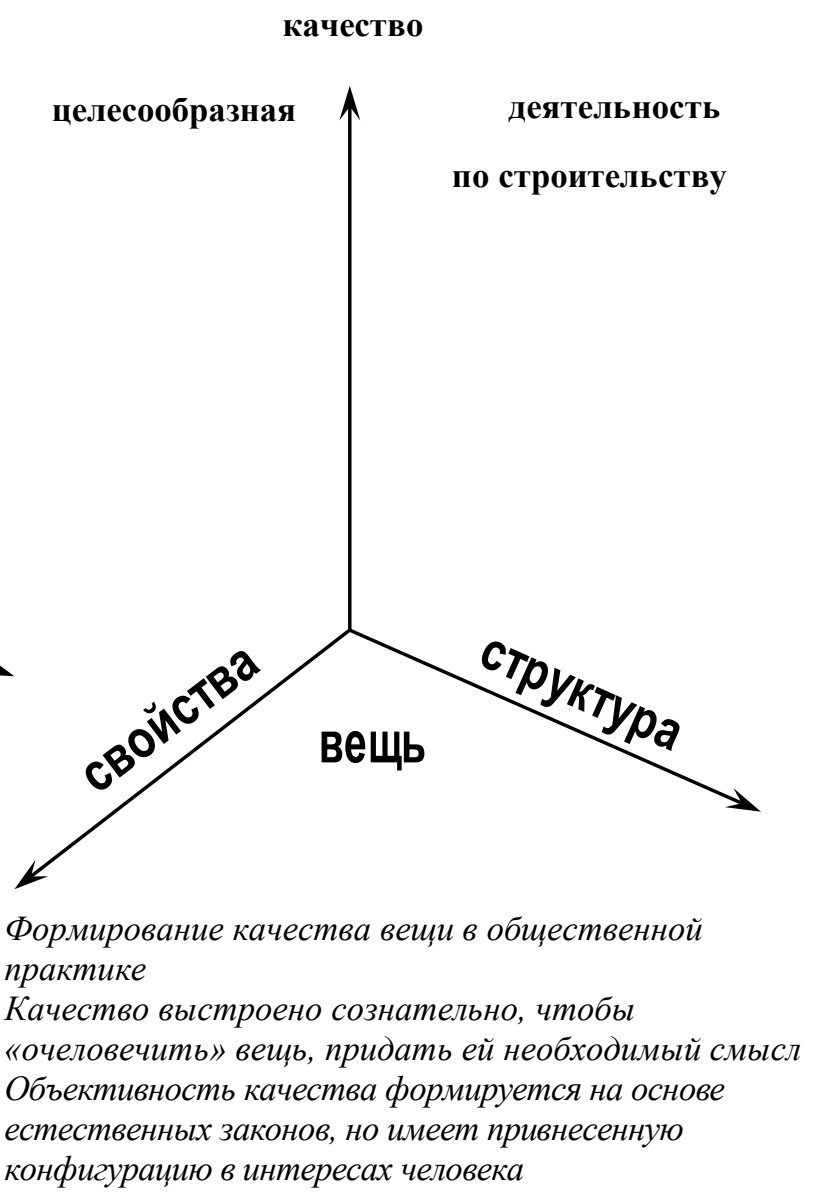

Формирование качества вещи

в природе

Качество выстроено бесиельно

и бессознательно

Объективность качества складывается

исключительно по естественным законам

\section{Рис. 1. Различия объективности качества естественного явления} и созданного человеком.

В качестве вещей, продуцируемых практической деятельностью человека, в качестве самой этой деятельности, сплетаются, сплавляются объективные свойства вещей и субъективные формы бытия человека. Качество изготовленных человеком вещей объективно, но в их объективности выражается разумность (или неразумность) человека. И здесь как раз находится узел противоречий производителя и потребителя. Развязать его можно только, согласовав взгляды на потребительские свойства товара производителя с реальной оценкой потребительских запросов и возможностей. Качество товаров следует разрабатывать исключительно с учетом тщательного маркетингового мониторинга, соответственно подтягивая резервы производства. Мы же продолжаем наблюдать разделенный рыночный механизм. Отсюда и проблемы с реализацией отечественной продукции.

Профессиональная деятельность подобно скульптору лепит качество вещи, опираясь на естественные свойства материала, возвышая их посредством таланта и труда до состояния, пробуждающего специфический интерес сознания. Вещи естественного происхождения тоже привлекают к себе человеческий интерес способностью вызывать эстетические чувства, оказывать лечебный эффект, быть материалом или условием производства быта, что объяснимо человек «вышел» из природы, оставшись ее особой частью. Однако при этом их качество сохраняет свою «естественную чистоту». Профессиональная деятельность - системный фактор в обеспечении качества товара, имеющего добавленную стоимость. Она, по положению, должна быть и начальным звеном в разработке идеологии управления качеством.

Качественную вещь может изготовить исключительно качественная профессиональная деятельность - это первый и основной закон качества производства. Природные катаклизмы способны на многое, им люди приобретением драгоценных камней, металлов, строительных материалов. Алмаз - детище естественной стихии. Минерал обладает исходным уникальным 


\begin{tabular}{|c|c|c|c|c|c|c|}
\hline \multirow{4}{*}{ Impact Factor: } & ISRA (India) & $=3.117$ & SIS (USA) & $=0.912$ & ICV (Poland) & $=6.630$ \\
\hline & ISI (Dubai, UAE & $=0.829$ & РИНЦ (Russia & $=0.156$ & PIF (India) & $=1.940$ \\
\hline & GIF (Australia) & $=0.564$ & ESJI (KZ) & $=8.716$ & IBI (India) & $=4.260$ \\
\hline & JIF & $=1.500$ & SJIF (Morocco & $=5.667$ & OAJI (USA) & $=0.350$ \\
\hline
\end{tabular}

природным качеством, однако изделия из алмаза приобретают столько новых качеств, в которых заинтересован человек, что естественное качество остается по сути важным лишь для обработчиков природного камня.

Конечный продукт из алмаза, будь он ювелирным украшением или техническим элементом, - результат профессиональной деятельности. На рынке драгоценных камней существует различие в интересе к исходному материалу, - из каких он месторождений, но главное там в другом: кто превратит алмазы в бриллианты. Качество бриллианта обусловлено соединением в изделии сырья и мастерства. А так как мастер выбирает сырье, то и вклад его профессионализма в качество изделия имеет решающее значение.

Отсюда второй закон качества производства: для обеспечения качества продукта необходима качественная подготовка специалистов, способных хранить и приумножать профессиональное мастерство.

Третий закон качества производства требует направленности профессиональной деятельности на совершенствование технологического процесса за счет интеграции с наукой и техническим прогрессом.
Понятие «качество», отражая предметное многообразие мира, обязано тем самым воспроизводить в себе объективное различие. Это осуществимо через структурирование качества. Структурированность качества особо значимый фактор в теории управления качеством. Целесообразно разделить качество на следующие семь структурных уровней по уровню значимости от вклада «человеческого фактора»[7-8]:

качество естественных предметов;

качество естественного материала;

качество переработанного естественного материала;

качество технического оснащения;

качество программного продукта;

качество производственной деятельности;

качество организации и управления производством.

Организационная и управленческая деятельность, нацеленная на производство качественного реализуемого продукта, сама требует проверки на качество. Аудит качества организации и управления качеством производства предполагает структурирование соответствующей деятельности. Наш исследовательский опыт проблемы подсказывает, что процесс организации и управления надо разложить на четыре составных (рисунок. 2).

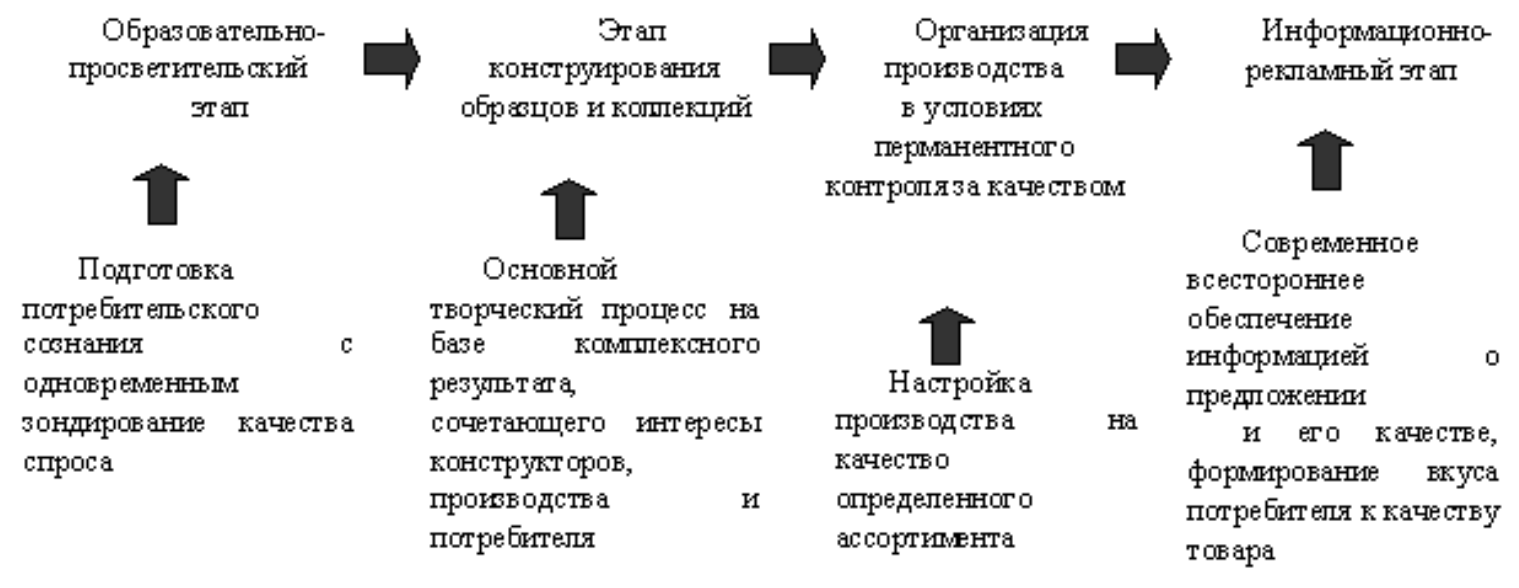

Рис. 2. Этапы включения творческой профессиональной деятельности в процесс формирования качества товара - составные организации и управления качеством производства.

\begin{abstract}
Логика сотворения качества создаваемых человеком вещей выдавливает на первый, крупный план, качество деятельности, акцентирует исследовательское внимание на признаках качественной деятельности, необходимости построения их системных отношений. Философская литература по
\end{abstract}

выделенной проблематике больше «молчит». Философы по-прежнему воюют. Сторонники объективности качества доказывают несостоятельность взглядов своих оппонентов, вместо того, чтобы смотреть на качество не только в контексте с объективной реальностью мира, но и преобразующей материальный мир человеческой, 


\begin{tabular}{|c|c|c|c|c|c|c|}
\hline \multirow{4}{*}{ Impact Factor: } & ISRA (India) & $=3.117$ & SIS (USA) & $=0.912$ & ICV (Poland) & $=6.630$ \\
\hline & ISI (Dubai, UAE & $=0.829$ & РИНЦ (Russia & $=0.156$ & PIF (India) & $=1.940$ \\
\hline & GIF (Australia) & $=0.564$ & ESJI (KZ) & $=8.716$ & IBI (India) & $=4.260$ \\
\hline & JIF & $=1.500$ & SJIF (Morocco & $=5.667$ & OAJI (USA) & $=0.350$ \\
\hline
\end{tabular}

профессиональной деятельностью. В духе домарксистского материализма невозможно разработать научно-философское учение о качестве, ибо старый материализм был, в сущности, философией созерцания, а не преобразования мира. К. Маркс в свое время учил: надо не только отражать мир, но и изменять его. Диалектика - материалистическое мировоззрение основано на практическом взаимодействии человека и природы. Деятельность, прежде всего творческая, - кредо диалектической философии и науки.

Универсальную модель отношений системных свойств профессиональной деятельности поясняет уже приводимая и предлагаемая нами схема (рисунок. 3).

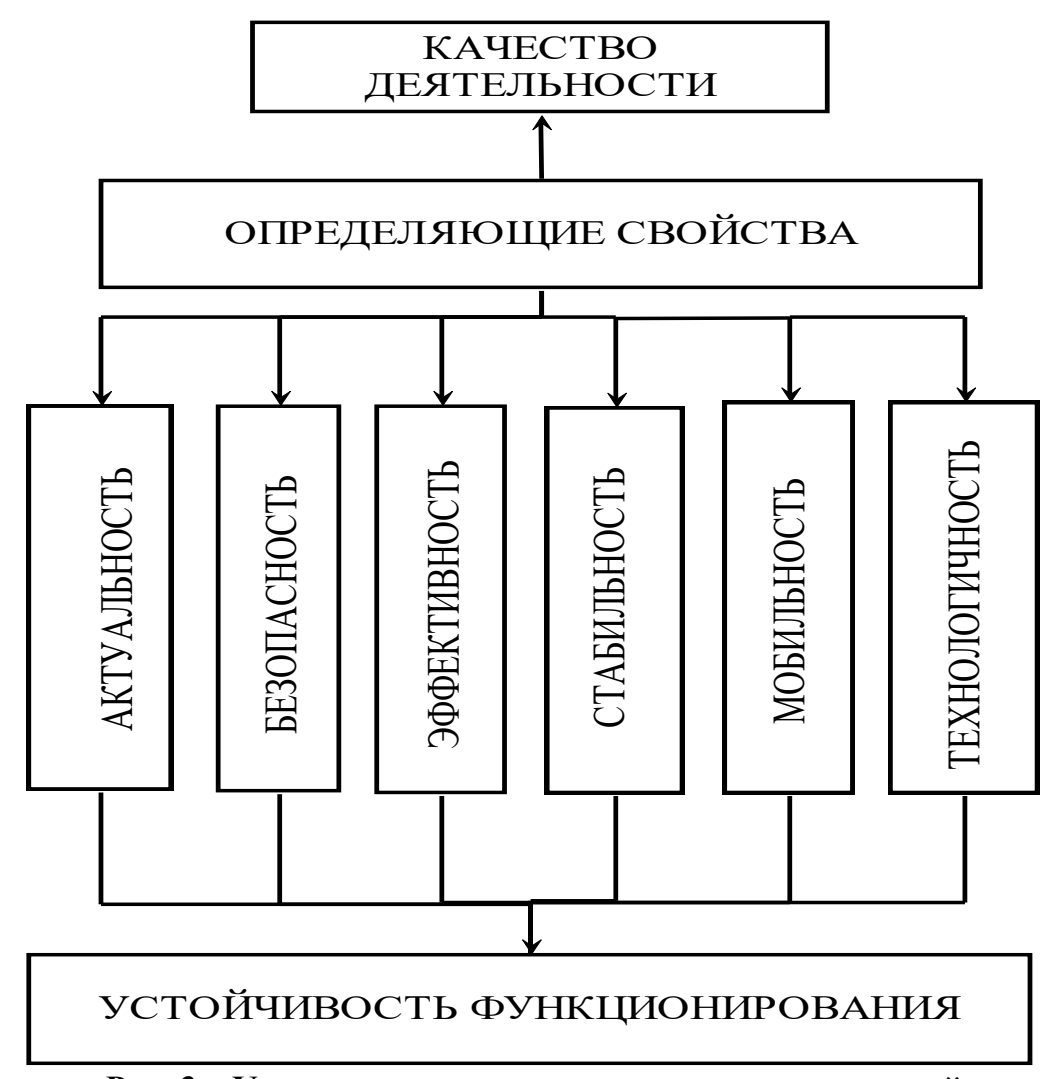

Рис. 3 - Универсальная модель системных отношений качественных свойств профессиональной деятельности.

Включенные в схему признаки профессиональной деятельности хорошо известны. С ними обычно и в научном и в практическом сознании связывают профессионализм. Новизна состоит не в самих признаках, а в представлении их системным образованием, которое придает им новый уровень значения. Представляя систему, исследователи обычно ссылаются на открытый Бертолланфи эффект системной связи свойств: расхождении суммы признаков системы и суммы признаков образующих систему элементов. Эффект, описанный Бертолланфи, позволяет судить о системной организации свойств, действий, явлений, как о наиболее эффективной форме отношений, что важно для эффективности управления, с одной стороны, и совершенстве организации, с другой (рис..3).
Управление качеством, надстраиваясь над философской его интерпретацией, следующий шаг делает по пути системной организации программы деятельности, разбираясь с расположением системных признаков деятельности, чтобы выстроенная система была бы жизненно устойчивой, актуальной и в меру безопасной.

Системный подход на данное время самый качественный способ познания и организации управления любой сложной деятельностью. Сомневающихся в наибольшей эффективности системного подхода наверное уже нет. Есть те, кто неадекватно воспринимает и оценивает бесспорные преимущества системного подхода, абсолютизируя его значение в ущерб другим методам, в частности, комплексному подходу. Комплексный подход в теории и на практике не растратил своей ценности в конкуренции с 


\begin{tabular}{|c|c|c|c|c|c|c|}
\hline \multirow{4}{*}{ Impact Factor: } & ISRA (India) & $=3.117$ & SIS (USA) & $=0.912$ & ICV (Poland) & $=6.630$ \\
\hline & ISI (Dubai, UAE & $=0.829$ & РИНЦ (Russia & $=0.156$ & PIF (India) & $=1.940$ \\
\hline & GIF (Australia) & $=0.564$ & ESJI (KZ) & $=8.716$ & IBI (India) & $=4.260$ \\
\hline & JIF & $=1.500$ & SJIF (Morocco & $=5.667$ & OAJI (USA) & $=0.350$ \\
\hline
\end{tabular}

системным, они, дополняют друг друга, и повышают эффективность деятельности как организационно-управленческой, так и познавательной.[9-10]

Качество деятельности удобнее анализировать с позиций системного подхода. Теорию же управления качеством, нам представляется, разумнее возвести на фундаменте комплексного рассмотрения.

Сложившая в специальном - не философском - познании (в практике тоже) ситуация вынуждает нас вернуться к различию, существующему между комплексным и системным методами, ибо слишком частыми стали подмены этих методов.

Системный подход принципиально выделяется способом построения знаний, при котором взаимоотношения образующих явления элементов, признаков, выстраиваются в зависимости от базового отношения, называемого системообразующим фактором. Система формируется подобно процессу кристаллизации путем последовательного приращивания составных.

Системно целесообразно выстраивать, к примеру, изделия из кожи, меха, текстиля, когда некоторое, согласованное состояние качества материала, берется за системообразующий фактор и к нему «привязывается» весь ряд, предлагаемый для производства. Качество и место на рынке в таком случае будут определяться качеством соответствующего состояния материала, использованного при изготовлении каждого конкретного ряда изделий.

Комплексный подход базируется на определенном качественном основании и требует всесторонности анализа качества явления, причем аспекты исследований могут быть равнозначными, и выступать в некоторой рейтинговой зависимости. Хорошим примером использования комплексного подхода является строительство управления качеством. Схематично оно выглядит приблизительно так, как показывает рисунок. 4.

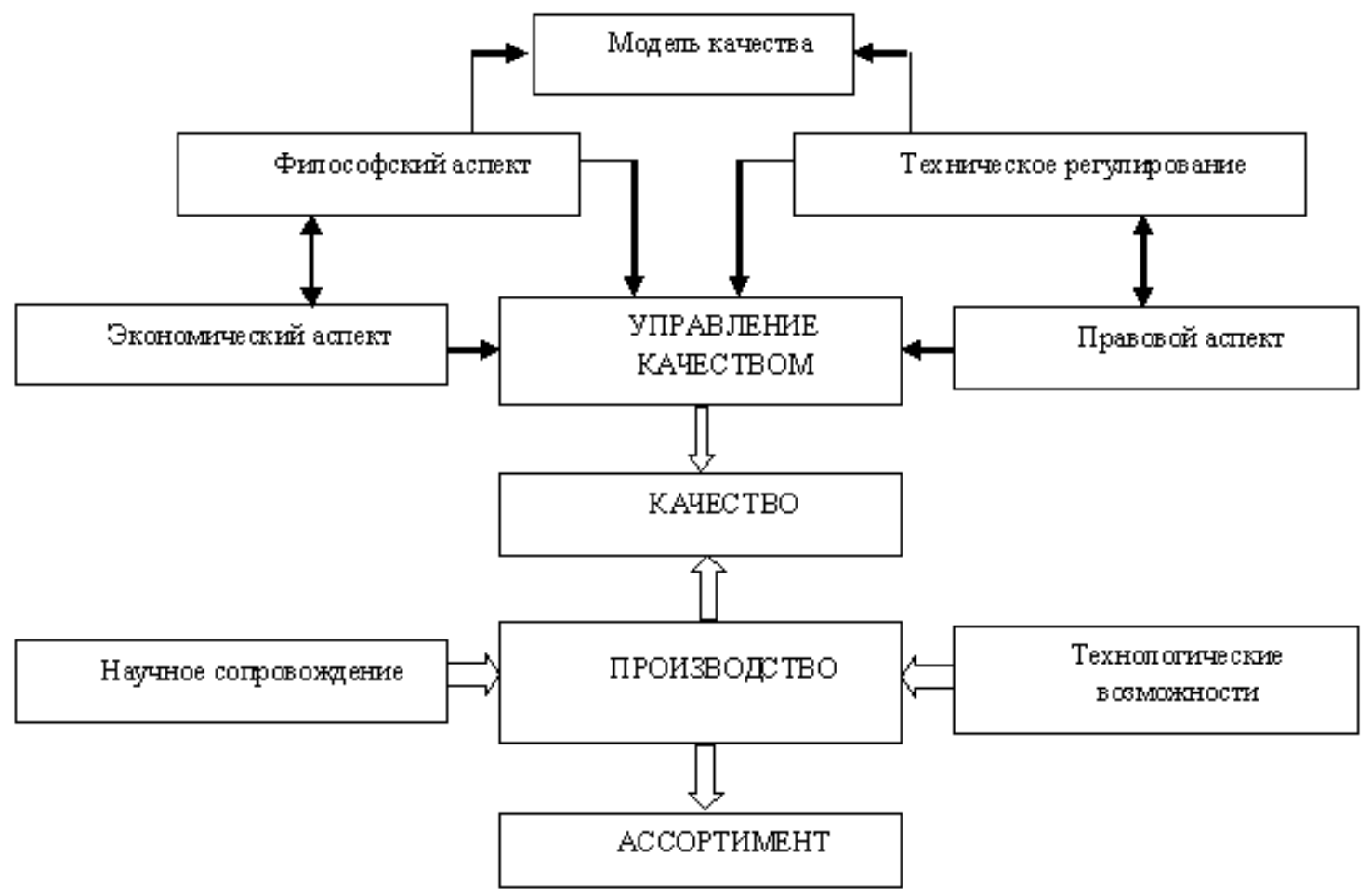

Рис. 4. Принципиальная схема комплексного управления качеством производства.

Приведенная схема демонстрирует взаимосвязи и ролевую ответственность основных элементов подготовки и осуществления процесса управления качеством производства. На ней достаточно четко просматриваются узловые отношения: связь философского аспекта с техническим регулированием, позволяющая конкретизировать методологические и теоретические проработки до уровня нормативнотехнических заданий; технического регулирования с правым аспектом, включая в последний использование патентных и лицензированных элементов: философского и экономического анализа, придающего первому конкретную предметную ориентацию в условиях рынка, а второму - методологическую 


\begin{tabular}{|c|c|c|c|c|c|c|}
\hline \multirow{4}{*}{ Impact Factor: } & ISRA (India) & $=3.117$ & SIS (USA) & $=0.912$ & ICV (Poland) & $=6.630$ \\
\hline & ISI (Dubai, UAE & $=0.829$ & РИНЦ (Russia & $=0.156$ & PIF (India) & $=1.940$ \\
\hline & GIF (Australia) & $=0.564$ & ESJI (KZ) & $=8.716$ & IBI (India) & $=4.260$ \\
\hline & JIF & $=1.500$ & SJIF (Morocco & $=5.667$ & OAJI (USA) & $=0.350$ \\
\hline
\end{tabular}

перспективу, зависимость качества производства от технологического состояния производства и научного оснащения.

Завершить философский анализ качества на уровне, необходимом для использования этих знаний в практике экономического управления качеством производства, поможет принципиальная схема взаимосвязи описывающих качество философских понятий, состыкованных с экономическими категориями. Она была разработана нами несколько лет назад. Наше возвращение к ней вынужденное. Причина в том, что у нас не оказалось выбора. Философы продолжают отвлеченный от конкретных форм экономической практики анализ качества в свете своих профессиональных интересов. Экономисты качество представляют узко эмпирически в рамках меркантильной заинтересованности.

Философия предупреждает, что объективизация качества имеет реальный смысл исключительно в гносеологическом аспекте его рассмотрения: при решении вопроса о природе качества. Действительно в ракурсе отношений «объект - субъект», качество первично - оно объективно по своей природе. Даже конструируя качество, мы лишены абсолютной свободы в своем творчестве. Профессиональное творчество ограничено объективными корнями создаваемого творчеством качества. Качество вещи объективно в материальном выражении, тогда как качество научной теории объективировано адекватностью отражения в ней объективного качества вещи, отношения которых воспроизводятся в научной теории. Система качества контроля приведена на рис. 5 .

В теории управления качеством важно правильно понимать диалектику в качестве организации производства; в качестве деятельности, организованной производством, наконец, в качестве производимого товара объективного и субъективного. Видный отечественный ученый, общественный деятель Л.П. Карсавин, чтобы подчеркнуть деятельный характер качества, связанный с субъективным творчеством профессионала, придумал термин «качествование».

Субъективная сторона качества товара раскрывается на рынке через сложные взаимоотношения создателей, посредников и потребителей. $\mathrm{C}$ ними пересекается своеобразие национального менталитета - в США и западноевропейских странах в толковании качества на рынке доминирует прагматический, утилитарный подход, в России традиционной стороной отношения к качеству товара была созерцательность, качественные товары и в наши дни для большинства россиян больше, чем нечто предназначенное исключительно для употребления.

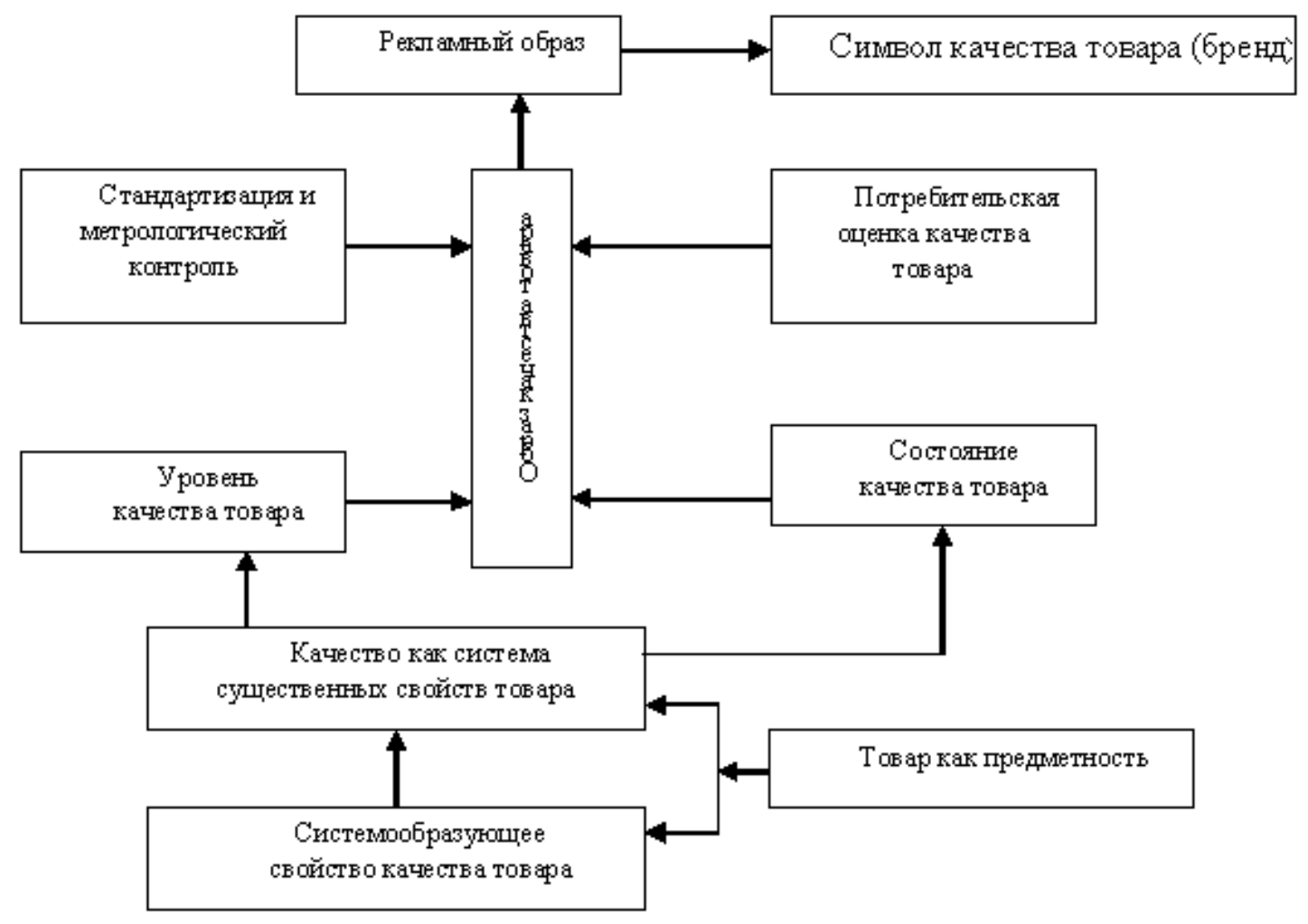

Рис. 5. Система качества контроля. 


\begin{tabular}{|c|c|c|c|c|c|c|}
\hline \multirow{4}{*}{ Impact Factor: } & ISRA (India) & $=3.117$ & SIS (USA) & $=0.912$ & ICV (Poland) & $=6.630$ \\
\hline & ISI (Dubai, UAE & $=0.829$ & РИНЦ (Russia & $=0.156$ & PIF (India) & $=1.940$ \\
\hline & GIF (Australia) & $=0.564$ & ESJI (KZ) & $=8.716$ & IBI (India) & $=4.260$ \\
\hline & JIF & $=1.500$ & SJIF (Morocco & $=5.667$ & OAJI (USA) & $=0.350$ \\
\hline
\end{tabular}

Творцам и производителям качественных товаров необходимо воспитывать сознание потенциальных потребителей своей продукции, исходя из того, что в условиях рынка качество товара - коллективный образ. Образ качества товара, фирменного производства конечно, можно раскрутить с помощью рекламы, но такая односторонность рискованна и опасна.

Устойчивость репутации качественного товара обеспечивается всем механизмом рынка, в том числе и его обширной инфраструктурой. Просвещенный потребитель активно включается в процесс «борьбы» за качество. Нежелание расходовать достойные средства на просвещение потребителя, стремление «обуть» его ложной, поверхностной рекламой неизбежно обернется бумерангом.

К сожалению, многие российские производители не боятся бумеранга. Они знают, что долго они в данном секторе производства не задержатся. Пока рынок расставит все по своим местам, отреагирует надлежащим образом на псевдо качество, они будут другими и эта «лабуда» для них потеряет актуальность.

Хотя специалисты и считают, что российский рынок качнулся в сторону качества продукции, объективно ситуация на рынке существенно не изменилась. Те малые проценты, на которых строятся обнадеживающие выводы, далеки от того, чтобы быть качественными характеристиками.

Условием выбора потребителем товара, в большом ассортименте предложенного на рынке, является совпадение его технических параметров с условными характеристиками прогнозируемой потребности. С этой точки зрения стратегия управления предприятием должна быть построена по принципу «следящей системы» с обратной связью, т.е. она должна обеспечивать потребителей продукцией, удовлетворяющей их специфическим требованиям по качеству и сопутствующему сервису при её сбыте, всё время отслеживая при этом степень такого удовлетворения (см. схему рис. 6).[11-12]

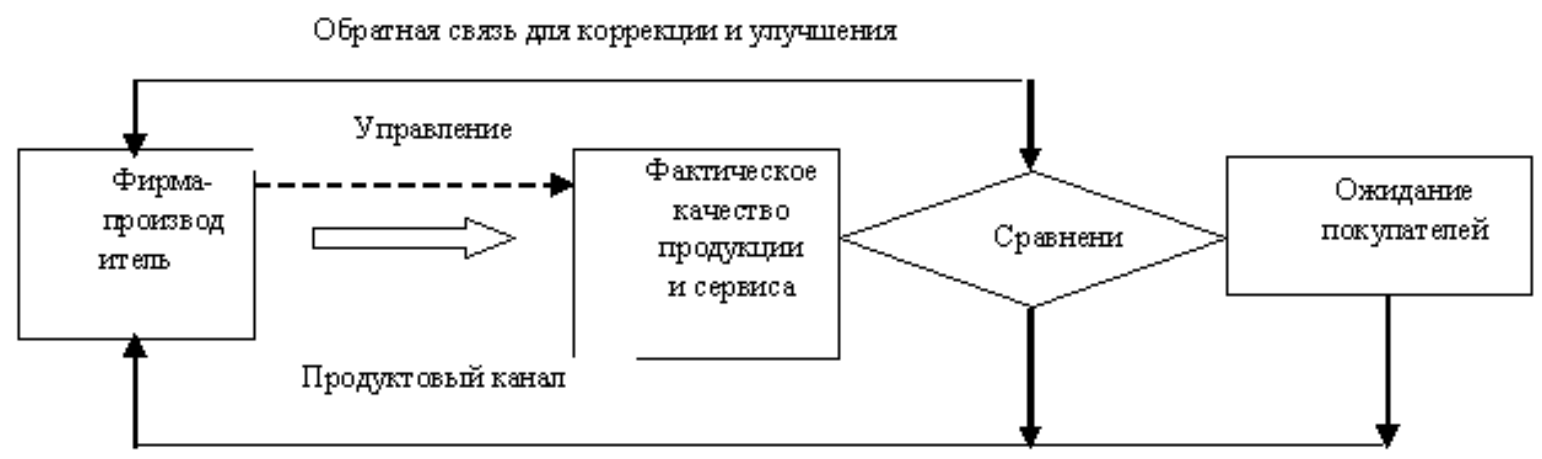

Рис. 6. Система удовлетворения потребителей.

Отслеживание качества товаров и сопутствующего сервиса состоит из двух этапов. На первом этапе фирма-производитель посредством маркетинга изучает покупательские ожидания в качестве продукции и сервиса её продвижения. На основе этой информации определяются функциональные спецификации для новых видов продукции и качества сервиса, которые будут зависеть от способности определения покупательских ожиданий и способности адаптировать технологии производства к изменению покупательских ожиданий.

Второй этап заключается в периодическом «измерении» рассогласования между фактическим и ожидаемым уровнем качества продукции и сопутствующего сервиса. В соответствии с величиной рассогласования деятельность предприятия должна быть направлена на выработку управляющих воздействий на организационно-технологические подразделения с целью уменьшения расхождения и внедрение новых методов оценки параметров качества.

Моделью оценки качества продукции является кортеж:

$$
W=\langle X, P, A\rangle,
$$

где $X$ - множество возможных вариантов решений (объектов), таких, что $x \in X-$ элемент этого множества, заданный на $\mathrm{X}$ посредством некоторых правил технологии изготовления и дистрибьюции товара; $P$ - исчислимое множество показателей качества и соответствующих им шкал измерений; $A$ - алгоритм оценки, реализующий логику сравнительной оценки альтернатив в форме «лучше-хуже».

Любое решение $x \in X$ представляется вектором $P(x)=\left(P_{1}(x), \ldots, P_{m}(x)\right)$ в $m$ мерном пространстве показателей качества, определяемом как декартово произведение 


\begin{tabular}{|c|c|c|c|c|c|c|}
\hline \multirow{4}{*}{ Impact Factor: } & ISRA (India) & $=3.117$ & SIS (USA) & $=0.912$ & ICV (Poland) & $=6.630$ \\
\hline & ISI (Dubai, UAE & $=0.829$ & РИНЦ (Russia & $=0.156$ & PIF (India) & $=1.940$ \\
\hline & GIF (Australia) & $=0.564$ & ESJI (KZ) & $=8.716$ & IBI (India) & $=4.260$ \\
\hline & JIF & $=1.500$ & SJIF (Morocco & $=5.667$ & OAJI (USA) & $=0.350$ \\
\hline
\end{tabular}

$P=P_{1} \times \ldots \times P_{m} \subset R^{m}, \quad$ где $\quad P_{j}$, $(j=\overline{1, m)}$ - множество допустимых значений $j$-го показателя, являющееся подмножеством множества вещественных чисел $R$.

Оценка качества продукции состоит в определении степени соответствия оцениваемого объекта целям его функционирования. Цель может быть задана косвенно - с помощью «эталона» качества. Эталоном качества является совокупность $\left\{P_{j d}\right\}$ базовых значений показателей качества производства и сбыта продукции, которые в наибольшей степени удовлетворяют ожидания потребителей.

Числовое представление уровня качества можно представить кортежем:

$$
A=\left\langle\varphi, P, P_{\delta}\right\rangle,
$$

где $\varphi: P \times P_{\delta} \rightarrow R$ - отображение множества $P \times P_{\delta} \subset R^{m}$ на множество действительных чисел $\boldsymbol{R}$, т.е. $A$ является многомерной шкалой оценки уровня качества. Откуда следует, что $W=\left\langle X, P, P_{\delta}, \varphi\right\rangle$, для $\quad$ любого $\quad x \in X$ устанавливает число, зависящее от положения точки

(вектора)

$$
P(x)=\left(P_{1}(x), \ldots, P_{m}(x)\right)
$$

пространстве показателей качества. При оценке уровня качества применяются несколько видов шкалирования.

1. Шкалирование отношения. Состоит в определении относительных показателей качества $\omega_{j}=P_{j} / P_{j \delta}$, которые определяют, во сколько раз оцениваемый объект лучше или хуже базового по $j$-му показателю качества $(j=\overline{1, m)}$. Операция шкалирования одновременно является операцией нормировки.

2. Шкалирование разности с нормировкой. Заключается в представлении оценки уровня качества по $j$-му показателю качества в виде $\omega_{j}=\left(P_{j \delta}-P_{j}\right) / P_{j \delta}$, где выраженный в процентах коэффициент $\omega_{j}$ показывает, насколько оцениваемый объект лучше или хуже базового. 


\begin{tabular}{|c|c|c|c|c|c|c|}
\hline \multirow{4}{*}{ Impact Factor: } & ISRA (India) & $=3.117$ & SIS (USA) & $=0.912$ & ICV (Poland) & $=6.630$ \\
\hline & ISI (Dubai, UAE & $=0.829$ & РИНЦ (Russia & $=0.156$ & PIF (India) & $=1.940$ \\
\hline & GIF (Australia) & $=0.564$ & ESJI (KZ) & $=8.716$ & IBI (India) & $=4.260$ \\
\hline & JIF & $=1.500$ & SJIF (Morocco & $=5.667$ & OAJI (USA) & $=0.350$ \\
\hline
\end{tabular}

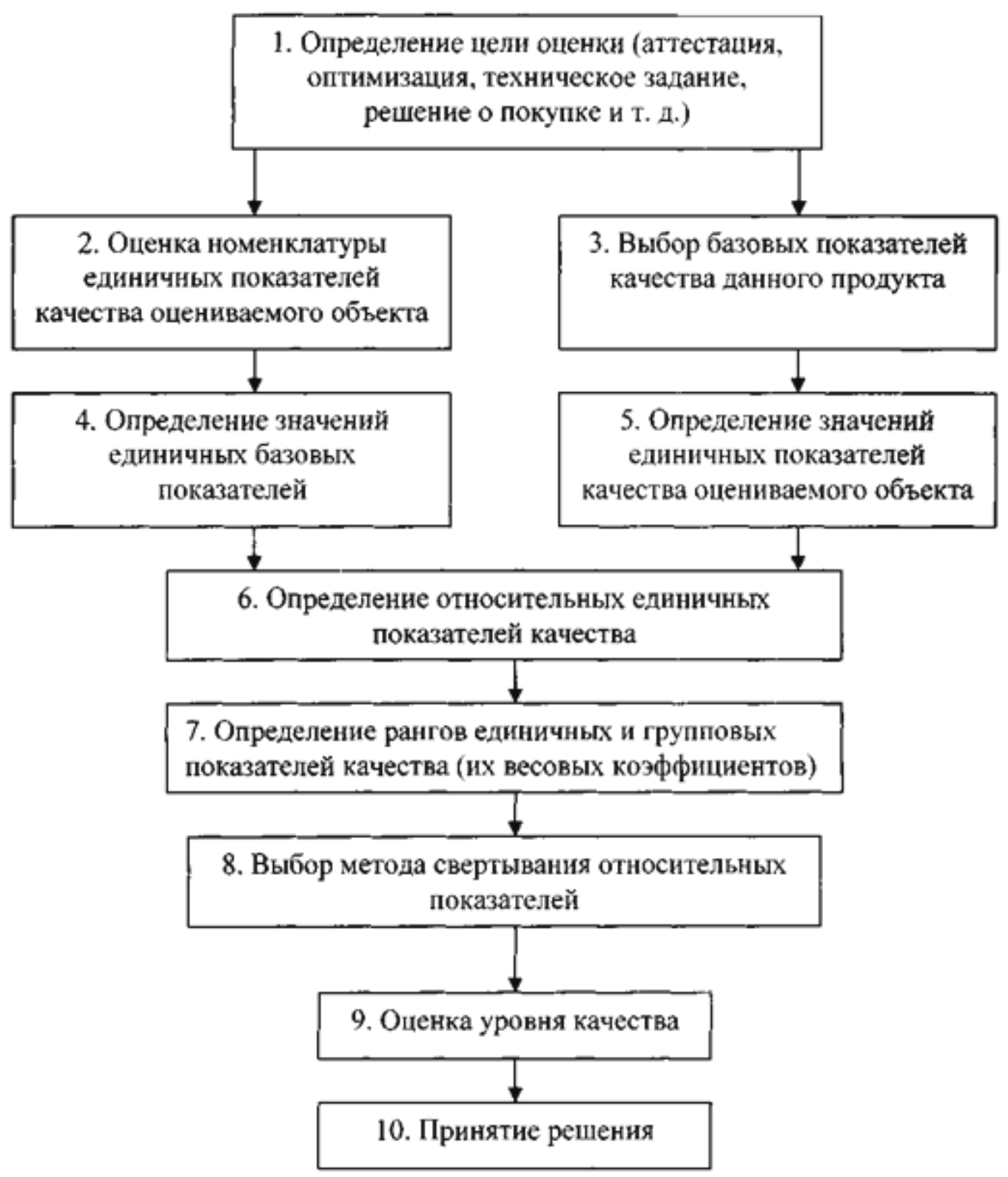

Рис. 7. Алгоритм комплексной оценки уровня качества объекта.

3. Многомерное шкалирование. Основано на определении обобщенного показателя $W(\omega)$, где $\omega=\left(\omega_{1, \ldots,}, \omega_{m}\right)$ - вектор относительных показателей качества. Обобщенный показатель характеризует степень соответствия объекта своему назначению. Таким образом, приходим к алгоритму оценки уровня качества продукции и сервиса в каждом конкретном случае. Алгоритм комплексной оценки уровня качества представлен на рис. 7.

На заключительном этапе при принятии решения, во-первых, необходимо решить, насколько приемлем результат (допустима ли точность и достоверность оценки). Если он не соответствует предъявляемым требованиям, может быть принято решение о проведении повторной оценки, дополнительных исследований для получения новой информации и т.д. Если же результат достаточно объективен, в зависимости от целей оценки принимаются соответствующие решения. Например, если целью оценки качества нескольких возможных вариантов продукции является отбор того, который в наибольшей степени отвечает запросам потребителей, то вариант, получивший наивысшую оценку, может быть принят к производству [23]. 


\begin{tabular}{|c|c|c|c|c|c|c|}
\hline \multirow{4}{*}{ Impact Factor: } & ISRA (India) & $=3.117$ & SIS (USA) & $=0.912$ & ICV (Poland) & $=6.630$ \\
\hline & ISI (Dubai, UAE & $=0.829$ & РИНЦ (Russia & $=0.156$ & PIF (India) & $=1.940$ \\
\hline & GIF (Australia) & $=0.564$ & ESJI (KZ) & $=8.716$ & IBI (India) & $=4.260$ \\
\hline & JIF & $=1.500$ & SJIF (Morocco & $=5.667$ & OAJI (USA) & $=0.350$ \\
\hline
\end{tabular}

\section{Прогнозирование затрат на качество при разработке нового ассортимента обуви}

В значительной степени причина неконкурентоспособности отечественной обуви заключалась в ошибочности методологии измерения и оценки её качества. Проблема состоит в определённом несовпадении оценки качества обуви, проектируемого на этапе разработки, сформированного на этапе производства и проверенного при окончательном контроле перед реализацией с потребительской оценкой качества. Разрыв между реальным качеством и требованиями к нему потребителей оказывает существенное влияние на потребительские предпочтения, а следовательно, и на конкурентоспособность. Чем меньше этот разрыв, тем выше конкурентоспособность обуви. Сложность заключается в том, что потребитель при оценке качества обуви ориентируется в значительной мере не на регламентируемые нормативными документами показатели качества, а на собственные вкусы и представления о том, какой должна быть обувь. Причём иногда представления о качестве у многих потребителей поверхностные, на уровне в основном органолептических показателей, которые не всегда достаточно полно и объективно характеризуют обувь.

Очень часто необходимость в оценке конкурентоспособности возникает ещё до появления новой продукции, т.е. на этапе проектирования и разработки. Так как уровень затрат в период потребления и эксплуатации более чем на $80 \%$ зависит от характеристик обуви, закладываемых на разных стадиях её разработки. На стадии рабочего проектирования и отработки опытного образца конструктор может воздействовать на снижение не более $15 \%$ этих затрат, а когда изделие поставлено на производство, то изменять этот показатель удаётся в пределах всего лишь $5 \%$.

Поэтому на предпроектной стадии создания новой продукции должна осуществляться разработка многовариантного прогноза, представляющего собой информацию о возможной технической реализации и сроках достижения выявленной цели.

В связи с этим задача исследования особенностей потребительского спроса на обувь является основной для повышения качества и конкурентоспособности выпускаемой продукции. Необходимо установить, по каким критериям покупатель оценивает качество, потому что он будет стараться приобрести обувь с желательной для него комбинацией свойств.

Для того чтобы оценить значимость показателей потребительского качества обуви на стадиях её проектирования, производства и реализации, нами был использован экспертный метод персональных оценок - ранжирование, который позволяет в достаточной мере учесть мнение как специалистов-изготовителей обуви, так и потенциальных её потребителей.

Экспертам предлагается проранжировать совокупность факторов, определяющих потребительское качество обуви. Исходные ранги преобразуются сначала таким образом:

$$
R_{j}=\sum_{i=1}^{m} r_{i j}
$$

где $R_{j}-$ сумма преобразованных рангов по всем экспертам для фактора $j ; r_{i j}-$ преобразованный ранг, присвоенный $i$-м экспертом $j$-му фактору; $m$ - число экспертов; $n-$ число факторов.

Затем вычисляются веса факторов:

$$
\begin{aligned}
& W_{i j}=\frac{r_{i j}}{\sum_{i=1}^{m} r_{i j}}, \\
& W_{j}=\frac{\sum_{i=1}^{m} W_{i j}}{\sum_{i=1}^{m} \sum_{j=1}^{n} W_{i j}},
\end{aligned}
$$

где $W_{j}-$ средний вес $j$-го фактора по всем экспертам.

Группа экспертов, состоящая из 100 человек, в ходе опроса была разделена на две группы: потребители и изготовители. К кандидатуре участника опроса из группы изготовителей предъявлялся ряд требований:

специальное образование;

занимаемая должность;

трудовой стаж.

Для поиска экспертов были привлечены ведущие специалисты обувных предприятий городов ЮФО: Шахты, Ростова-на-Дону, Краснодара, Волгограда и др. Для работы в качестве экспертов также привлекались преподаватели кафедры «Технология изделий из кожи, стандартизация и сертификация» ЮжноРоссийского государственного университета экономики и сервиса.

Эксперты при анкетировании ранжировали показатели по степени важности, т.е. по степени 


\begin{tabular}{|c|c|c|c|c|c|c|}
\hline \multirow{4}{*}{ Impact Factor: } & ISRA (India) & $=3.117$ & SIS (USA) & $=0.912$ & ICV (Poland) & $=6.630$ \\
\hline & ISI (Dubai, UAE & $=0.829$ & РИНЦ (Russia & $=0.156$ & PIF (India) & $=1.940$ \\
\hline & GIF (Australia) & $=0.564$ & ESJI (KZ) & $=8.716$ & IBI (India) & $=4.260$ \\
\hline & JIF & $=1.500$ & SJIF (Morocco & $=5.667$ & OAJI (USA) & $=0.350$ \\
\hline
\end{tabular}

их влияния на качество обуви. В качестве объекта исследования была выбрана женская обувь сапожки осенне-весеннего ассортимента.

В ходе опроса экспертам был предложен опросный лист, содержащий факторы, влияющие на качество и конкурентные преимущества обуви на стадиях проектирования, производства и реализации (табл. 4).

Опрашиваемым было предложено расположить факторы в порядке убывания степени их влияния на качество и конкурентоспособность обуви (проранжировать), т.е. фактор, который эксперт считает наиболее важным, получает более высокий ранг- 1 , а остальные - по степени уменьшения их влияния на конкурентные преимущества обуви, т.е. 2, 3 места и т.д. Если же эксперт не мог принять решение о присвоении места для двух или нескольких рядом стоящих факторов, то он присваивал им один и тот же ранг.[13-14]
Обработка результатов экспертного опроса была выполнена на ПЭВМ по специальной программе «RANG». Характер распределения результатов ранжирования указывает на то, что мнения потребителей и изготовителей, работавших в качестве экспертов, совпадают по многим пунктам.

На стадии проектирования установлены значимые показатели качества: соответствие направлениям моды $-\mathrm{X}_{1}$; форма носочной части $\mathrm{X}_{2}$; форма каблука - $\mathrm{X}_{3}$; высота каблука - $\mathrm{X}_{4}$; конструкция заготовки верха обуви - $\mathrm{X}_{6}$; дизайн модели - $\mathrm{X}_{7}$. Менее значимые: цветовое решение $-\mathrm{X}_{8}$; гибкость обуви $-\mathrm{X}_{9}$; толщина подошвы - $\mathrm{X}_{5}$. После статистической обработки результатов экспертного опроса выяснилось, что все вышеперечисленные факторы остались значимыми.

Таблица 4. Анкетный опросный лист.

\begin{tabular}{|c|c|}
\hline Факторы & Ранг \\
\hline \multicolumn{2}{|l|}{ Стадия проектирования обуви } \\
\hline \multicolumn{2}{|l|}{$\mathrm{X}_{1}$ - соответствие направлениям моды } \\
\hline \multicolumn{2}{|l|}{ 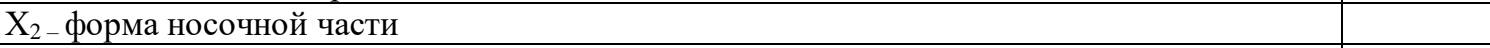 } \\
\hline \multicolumn{2}{|l|}{$\mathrm{X}_{3}$ - форма каблука } \\
\hline \multicolumn{2}{|l|}{$\mathrm{X}_{4}$ - высота каблука } \\
\hline \multicolumn{2}{|l|}{$\boldsymbol{X}_{5}-$ толщина подошвы } \\
\hline \multicolumn{2}{|l|}{$\mathrm{X}_{6}-$ конструкция заготовки верха обуви } \\
\hline \multicolumn{2}{|l|}{$\mathrm{X}_{7}$ - дизайн модели } \\
\hline \multicolumn{2}{|l|}{$\mathrm{X}_{8}-$ цветовое решение } \\
\hline \multicolumn{2}{|l|}{ 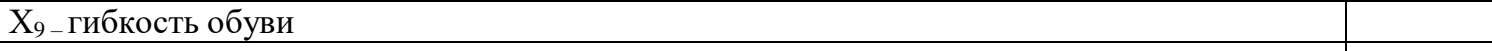 } \\
\hline \multicolumn{2}{|l|}{ Стадия производства обуви } \\
\hline \multicolumn{2}{|l|}{$\mathrm{X}_{1}-$ вид материала верха } \\
\hline \multicolumn{2}{|l|}{$\mathrm{X}_{2}$ - вид материала низа } \\
\hline \multicolumn{2}{|l|}{$\mathrm{X}_{3}$ - качество соединения деталей верха } \\
\hline \multicolumn{2}{|l|}{$\mathrm{X}_{4}$ - качество исполнения заготовки верха обуви } \\
\hline \multicolumn{2}{|l|}{$\mathrm{X}_{5}-$ жёсткость носка } \\
\hline \multicolumn{2}{|l|}{$\mathrm{X}_{6}-$ жёсткость задника } \\
\hline \multicolumn{2}{|l|}{$\mathrm{X}_{7}$ - прочность крепления деталей низа } \\
\hline \multicolumn{2}{|l|}{ 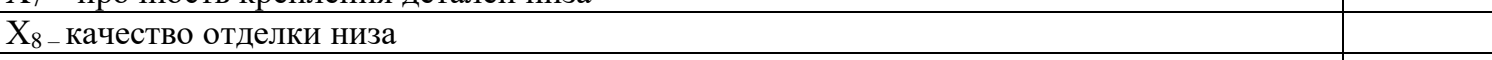 } \\
\hline \multicolumn{2}{|l|}{ Стадия реализации обуви } \\
\hline \multicolumn{2}{|l|}{$\mathrm{X}_{1}$ - привлекательность внешнего вида } \\
\hline \multicolumn{2}{|l|}{$\mathrm{X}_{2}-$ новизна изделия } \\
\hline \multicolumn{2}{|l|}{$\mathrm{X}_{3}-$ масса обуви } \\
\hline \multicolumn{2}{|l|}{$\mathrm{X}_{4-\text { цена }}$} \\
\hline \multicolumn{2}{|l|}{$\mathrm{X}_{5}-$ престиж торговой марки } \\
\hline \multicolumn{2}{|l|}{$\mathrm{X}_{6}-$ реклама } \\
\hline \multicolumn{2}{|l|}{$\mathrm{X}_{7-\text { сервисные услуги }}$} \\
\hline $\mathrm{X}_{8-\text { качество упаковки }}$ & \\
\hline
\end{tabular}

На стадии производства для производителей и потребителей значимыми факторами являются: вид материала верха - $\mathrm{X}_{1}$; вид материала низа -
$\mathrm{X}_{2}$; качество соединения деталей верха - $\mathrm{X}_{3}$; качество исполнения заготовки верха обуви $-\mathrm{X}_{4}$; 


\begin{tabular}{|c|c|c|c|c|c|c|}
\hline \multirow{4}{*}{ Impact Factor: } & ISRA (India) & $=3.117$ & SIS (USA) & $=0.912$ & ICV (Poland) & $=6.630$ \\
\hline & ISI (Dubai, UAE & $=0.829$ & РИНЦ (Russia & $=0.156$ & PIF (India) & $=1.940$ \\
\hline & GIF (Australia) & $=0.564$ & ESJI (KZ) & $=8.716$ & IBI (India) & $=4.260$ \\
\hline & JIF & $=1.500$ & SJIF (Morocco & $=5.667$ & OAJI (USA) & $=0.350$ \\
\hline
\end{tabular}

прочность крепления деталей низа $-\mathrm{X}_{7}$; жёсткость задника $-\mathrm{X}_{6}$; качество отделки низа $-\mathrm{X}_{8}$.

На стадии реализации значимыми показателями качества обуви для всех экспертов являются: привлекательность внешнего вида $-\mathrm{X}_{1}$; новизна изделия $-\mathrm{X}_{2}$; цена $-\mathrm{X}_{4}$; масса обуви $-\mathrm{X}_{3}$; престиж торговой марки - $\mathrm{X}_{5}$. Менее значимые реклама $-\mathrm{X}_{6}$; сервисные услуги $-\mathrm{X}_{7}$; качество упаковки $-\mathrm{X}_{8}$.

Для прогнозирования затрат на качество с учётом требований потребителей при разработке нового ассортимента обуви, по результатам экспертного опроса на стадии проектирования необходимо определить веса всех значимых факторов по формуле (5).

Предположим, что известны затраты на улучшение качества одной единицы продукции для каждого фактора, которые определяются вектором:

$$
p=\left(p_{1}, p_{2}, \ldots, p_{n}\right)
$$

Тогда можно определить ожидаемые затраты на изменение качества проектируемого изделия:

$$
M(X)=p_{1} w_{1}+p_{2} w_{2}+\ldots+p_{n} w_{n} \text { (7) }
$$

Такой метод оценки ожидаемых затрат можно использовать и на стадиях производства и реализации продукции.

Проведённые исследования охватывают весь спектр покупательских и производственных требований к обуви, влияющих на её конкурентоспособность, а также позволяют прогнозировать затраты на повышение качества на всех стадиях жизненного цикла продукции и должны быть учтены производителями при формировании ассортимента обуви [15-16].

Во многих отраслях при подготовке массового производства новых образцов возникает необходимость их сравнительной оценки для принятия решения о последовательности изготовления или выбора одного из ряда спроектированных $(1,2)$, а также для весьма действенной рекламы, представления покупателю технических преимуществ изделия. В обычной практике эта задача решается экспертной оценкой изделия специалистами с привлечением трудно сравнимых технико-экономических показателей, имеющих разный уровень значимости и размерности измерения, например, изделия имеют разный вес в килограммах, стоимость - в граммах, воздухопроницаемость дм $^{3} / \mathrm{M}^{2} \mathrm{c}$. Нахождение особенностей оценки изделия достигают путём сложного компромисса за счёт утери специфики каждого показателя, введения критикуемых субъективных коэффициентов «важности» и др., что трудно обосновать и доказать.

Эту часть интеллектуальной задачи можно более доказательно решать в человеко-машинной системе с сетевой архитектурой для оценки продукта. Например, такую оценку можно получить в системе управления конструкторской подготовки лёгкой, пищевой и других отраслей промышленности путём визуализации суммарной оценки продукции. Тогда обеспечение управления сводится к выбору такой траектории в многомерном фазовом пространстве свойств изделий, которая лучшим образом удовлетворяет главной функции сложной системы критерий (например, завоевание рынка изделий, производство и реализация всей продукции в заданные сроки). В традиционном системном анализе в таких задачах проводят формализацию сложной системы путём её декомпозиции на выбранное количество подсистем. Однако в этом случае связи - отношения между подсистемами не имеют топологии, они формально разделены. Это можно компенсировать таким методом формализации, в котором будут выявлены связи отношения с помощью математического аппарата теорий множества и общей топологии и в частности модели флуктуационной капсулы параметров (3). Реализация такого сравнительного анализа ряда изделий между собой и выявления приоритета относительно проста (рис. .8).

Всё информационное поле разделено на плоскости четырьмя линиями, образующими 8 векторов и 8 зон (их может быть и другое количество). На линии наносится информация о каждом из восьми выбранных в нашем примере свойств. В этом случае для характеристики обуви: спрос - себестоимость, вес и гибкость, паропроницаемость и влагоёмкость, эстетические свойства (баллы) - экологическое (санитарное) загрязнение ненатуральными материалами. На лучи графика откладываются полученные экспериментальные числовые данные, если имеются в естественных единицах измерения, например, себестоимость в рублях, вес в граммах, а спрос и эстетические свойства в баллах, приданных им специалистами. Полученная в виде многоугольника наглядная визуализация сложной системы позволяет проектировщику или покупателю принять правильное решение по сравнительной оценке разных моделей изделий, ранжирования их в предпочтительный ряд путём сравнения площадей многоугольников.[17-18] 


\begin{tabular}{|c|c|c|c|c|c|c|}
\hline \multirow{4}{*}{ Impact Factor: } & ISRA (India) & $=\mathbf{3 . 1 1 7}$ & SIS (USA) & $=0.912$ & ICV (Poland) & $=6.630$ \\
\hline & ISI (Dubai, UAE & $=0.829$ & РИНЦ (Russia & $=0.156$ & PIF (India) & $=1.940$ \\
\hline & GIF (Australia) & $=0.564$ & ESJI (KZ) & $=8.716$ & IBI (India) & $=4.260$ \\
\hline & JIF & $=1.500$ & SJIF (Morocce & $=5.667$ & OAJI (USA) & $=0.350$ \\
\hline
\end{tabular}

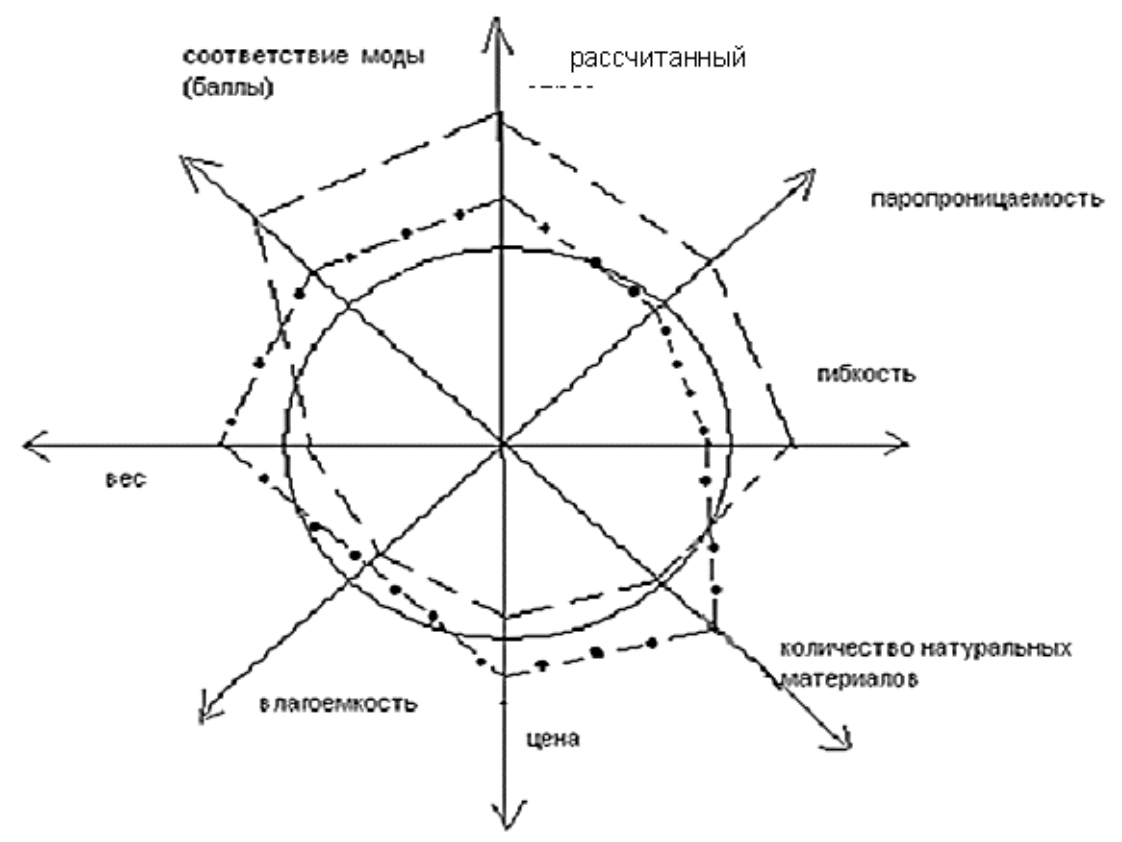

Рис. 8. Суммарные свойства по комбинации показателей образцов обуви.

В этом рисунке имеется кроме визуальной ещё и ряд другой информации. Например, величины площадей фигур, заключённых между лучами, их суммы выявляют преимущество площадей «положительных» показателей высоких эстетических свойств и спроса на гибкую обувь, над изделием с большим весом, себестоимостью и искусственными деталями менее экологически чистыми. Так, на примере, показанном на рис. 3.10, преимущество по комбинации показателей двух образцов имеет N1, характеризующийся большей суммарной площадью в «положительных» секторах свойств. Это действенный приём наглядной рекламы, помогающий выбрать образец с более высокими «суммарными» свойствами, трудно сопоставимыми между собой.

Такой метод выбора «лучшего» изделия относительно прост и нагляден, что позволяет принять правильное решение. Этот метод можно использовать для технической и деловой оценки различной продукции отраслей - лёгкой, пищевой, электроники (например, INFINITE, показанные на выставке CEBIT ) и др.

На уровне пересечения круга и осей проставлены величины восьми показателей нормированных (если они есть) или средние по ассортименту в своих единицах, прямыми соединены данные каждого образца $\mathrm{N} 1 \ldots, \mathrm{N} 2 \ldots$ и т.д., нанесенные на осях.

\section{О показателях оценки качества обуви}

В современных условиях при общей насыщенности рынка товарами народного потребления наиболее острой является проблема обеспечения соответствия качества предлагаемой продукции потребительским требованиям. Среди потребительских требований к обуви на первое место по значимости большинством выдвигается группа эргономических, определяемых понятием «комфортность».

Сертификационные испытания обуви строятся на основе действующей нормативной документации, в которой изложены технические требования, методы её испытания по определению основных показателей качества. В подтверждение сказанному, ниже приводятся показатели качества и методы испытания для их определения.

Что же такое Программа «Российское качество»? Из рекламных материалов организации следует, что она «выявляет продукцию и услуги высокого качества, представленные на российском рынке и информирует потребителей о них; даёт предприятию возможность доказать потребителям, что качество его продукции или услуги существенно выше стандартного уровня; даёт возможность органам государственного управления закупать продукцию и услуги высокого качества. Знак «Российское качество», право на использование которого предприятие получает при успешном участии в Программе, становится наиболее авторитетным свидетельством такого качества. По итогам участия в Программе предприятие может 


\begin{tabular}{|c|c|c|c|c|c|c|}
\hline \multirow{4}{*}{ Impact Factor: } & ISRA (India) & $=3.117$ & SIS (USA) & $=0.912$ & ICV (Poland) & $=6.630$ \\
\hline & ISI (Dubai, UAE & $=0.829$ & РИНЦ (Russia & $=0.156$ & PIF (India) & $=1.940$ \\
\hline & GIF (Australia) & $=0.564$ & ESJI (KZ) & $=8.716$ & IBI (India) & $=4.260$ \\
\hline & JIF & $=1.500$ & SJIF (Morocco & $=5.667$ & OAJI (USA) & $=0.350$ \\
\hline
\end{tabular}

предъявить заинтересованным сторонам в качестве документов, свидетельствующих о высоком качестве, не только диплом, но также программу оценки и отчет по её результатам.

Результаты успешного участия в Программе можно использовать при проведении маркетинговых и рекламных компаний, при демонстрации своих возможностей клиентам и заказчикам на выставках и ярмарках, а также при участии в конкурсных торгах и тендерах. Для информирования о продукции со знаком «Российское качество» и предприятияхдипломантах Программы предусматривается:

проведение общероссийских, региональных и отраслевых презентаций продукции, удостоенной знака «Российское качество»;

выпуск общероссийских и отраслевых каталогов «Российское качество»;

выпуск Вестника Программы «Российское качество»;

размещение на льготных условиях информации о предприятии-дипломанте и продукции на интернет-сайте Программы www.roskachestvo.ru и других интернет-ресурсах;

участие на льготных условиях дипломантов программы в выставках и ярмарках, проводимых с участием Всероссийской организации качества;

публикации в отраслевых, региональных и общероссийских средствах массовой информации».

В соответствии с документами: «Положение о программе «Российское качество» ЦЭП ВОК №РК-01-02 и «Положение о программах оценки качества, используемых в программе «Российское качество» ЦЭП ВОК № РК-06-02 разработана Рабочая программа № РК-ПР-ЦЭП-47-02-05, которая включала пункты:

1) оцениваемая продукция;

2) номенклатура оцениваемых показателей качества продукции, их допустимые и оптимальные значения и баллы, им соответствующие;
3) определение фактических значений показателей качества;

4) оценка способности производства обеспечить стабильность качества продукции;

5) заключение о соответствии качества продукции высшему уровню.

Например, качество заявленных моделей повседневной мужской обуви оценивалось по четырем группам: функциональные показатели (1), характеризующие долговечность продукции; эргономические показатели (2); эстетические показатели (3); показатели качества упаковки и маркировки (4).

В первой группе выделены такие единичные показатели, как:

прочность ниточных креплений заготовок верха обуви, Н/см, при одной строчке;

прочность ниточных креплений заготовок верха обуви, Н/см, при двух строчках;

прочность крепления подошвы, Н/см;

остаточная деформация подноска, мм;

остаточная деформация задника, мм;

во второй группе:

масса полупары, г;

гибкость обуви, Н/см;

тепловое сопротивление верха обуви, ${ }^{2}$

${ }^{\circ} \mathrm{C} /$ Вт (для зимней обуви);

тепловое сопротивление низа обуви, $\mathrm{M}^{2}{ }^{\circ} \mathrm{C} / \mathrm{BT}$

(для зимней обуви);

в третьей:

силуэт, баллы;

внешний вид, баллы;

внутренняя отделка, баллы;

в четвёртой:

качество маркировки;

качество упаковки, баллы.

Допускаемые значения показателей, равно как и собственно их перечень установлены в соответствии с ГОСТ, указанными в табл. 2.

Таблица 2. Показатели качества и методы испытания для их определения.

\begin{tabular}{|l|l|}
\hline \multicolumn{1}{|c|}{ Наименование показателя качества } & \multicolumn{1}{|c|}{$\begin{array}{c}\text { Метод испытаний } \\
\text { (ГОСТ, норма и т.д.) }\end{array}$} \\
\hline \hline $\begin{array}{l}\text { 1. Обувь. Метод определения общей и остаточной деформации подноска и } \\
\text { задника }\end{array}$ & ГОСТ 9135-73 \\
\hline $\begin{array}{l}\text { 2. Обувь. Метод определения прочности крепления подошв } \\
\text { в обуви химических методов крепления }\end{array}$ & ГОСТ 9292-82 \\
\hline $\begin{array}{l}\text { 3. Обувь. Метод определения прочности ниточных швов } \\
\text { соединения деталей верха }\end{array}$ & ГОСТ 9290-76 \\
\hline 4. Обувь. Метод определения гибкости & ГОСТ 9718-88 \\
\hline 5. Обувь. Метод определения прочности крепления деталей низа & ГОСТ 9134-78 \\
\hline 6. Обувь. Метод определения массы & ГОСТ 28735-90 \\
\hline $\begin{array}{l}\text { 7. Обувь. Метод определения суммарного теплового } \\
\text { сопротивления обуви }\end{array}$ & ГОСТ 12.4.104-81 \\
\hline 8. Обувь. Правила приёмки & ГОСТ 9289-78 \\
\hline
\end{tabular}




\begin{tabular}{|c|c|c|c|c|c|c|}
\hline \multirow{4}{*}{ Impact Factor: } & ISRA (India) & $=3.117$ & SIS (USA) & $=0.912$ & ICV (Poland) & $=6.630$ \\
\hline & ISI (Dubai, UAE & $=0.829$ & РИНЦ (Russia) & $=0.156$ & PIF (India) & $=1.940$ \\
\hline & GIF (Australia) & $=0.564$ & ESJI (KZ) & $=8.716$ & IBI (India) & $=4.260$ \\
\hline & JIF & $=1.500$ & SJIF (Morocco) & $=5.667$ & OAJI (USA) & $=0.350$ \\
\hline
\end{tabular}

\begin{tabular}{|l|l|}
\hline 9. Обувь. Маркировка, упаковка, транспортирование и хранение & $\begin{array}{l}\text { ГОСТ 7296-81 } \\
\text { ГОСТ 16534-71 }\end{array}$ \\
\hline 10. Обувь. Определение сортности & ГОСТ 28371-89 \\
\hline $\begin{array}{l}\text { 11. Система показателей качества. Обувь. Номенклатура } \\
\text { показателей }\end{array}$ & ГОСТ 4.12-81 \\
\hline 12. Обувь. Термины и определения & ГОСТ 23251-83 \\
\hline 13. Обувь. Методы определения линейных размеров & ГОСТ 9133-78 \\
\hline 14. Колодки обувные. Технические условия & ГОСТ 3927-88 \\
\hline $\begin{array}{l}\text { 15. Практикум по технологии изделий из кожи / Под ред. В.Л. Раяцкаса. М., } \\
\text { 1981. }\end{array}$ & \\
\hline $\begin{array}{l}\text { 16. Система разработки и постановки продукции } \\
\text { на производство. Продукция лёгкой промышленности. } \\
\text { Основные положения }\end{array}$ & ГОСТ15.007-88 \\
\hline 17. Обувь повседневная. Технические условия & ГОСТ 26167-84 \\
\hline 18. Обувь. Нормы прочности & ГОСТ 21463-87 \\
\hline 19. Справочник обувщика. Технология. М. : Легпромбытиздат, 1989. & \\
\hline
\end{tabular}

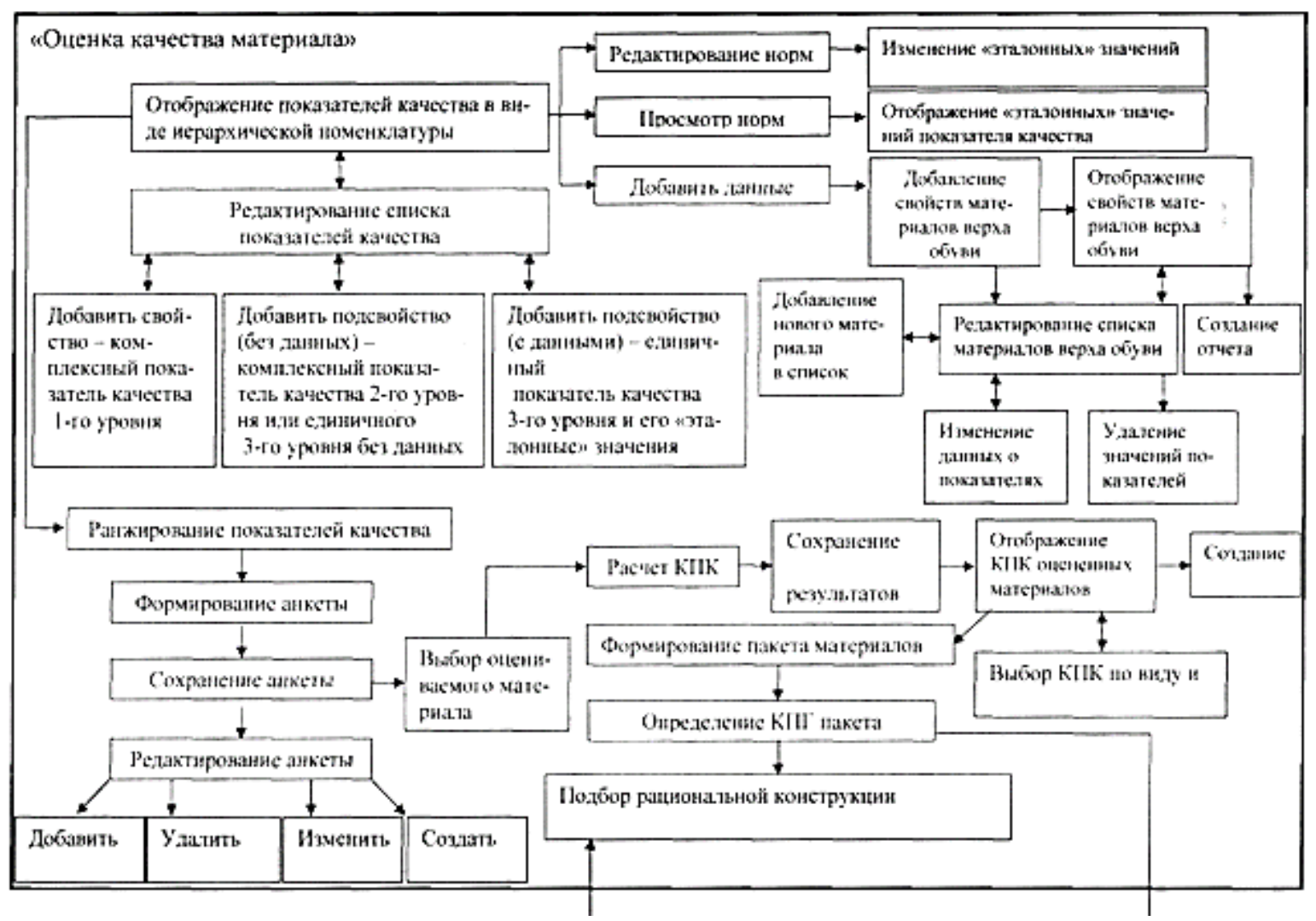




\begin{tabular}{|c|c|c|c|c|c|c|}
\hline \multirow{4}{*}{ Impact Factor: } & ISRA (India) & $=\mathbf{3 . 1 1 7}$ & SIS (USA) & $=0.912$ & ICV (Poland) & $=6.630$ \\
\hline & ISI (Dubai, UAE & $=0.829$ & РИНЦ (Russia & $=0.156$ & PIF (India) & $=1.940$ \\
\hline & GIF (Australia) & $=0.564$ & ESJI (KZ) & $=8.716$ & IBI (India) & $=4.260$ \\
\hline & JIF & $=1.500$ & SJIF (Morocce & $=5.667$ & OAJI (USA) & $=0.350$ \\
\hline
\end{tabular}

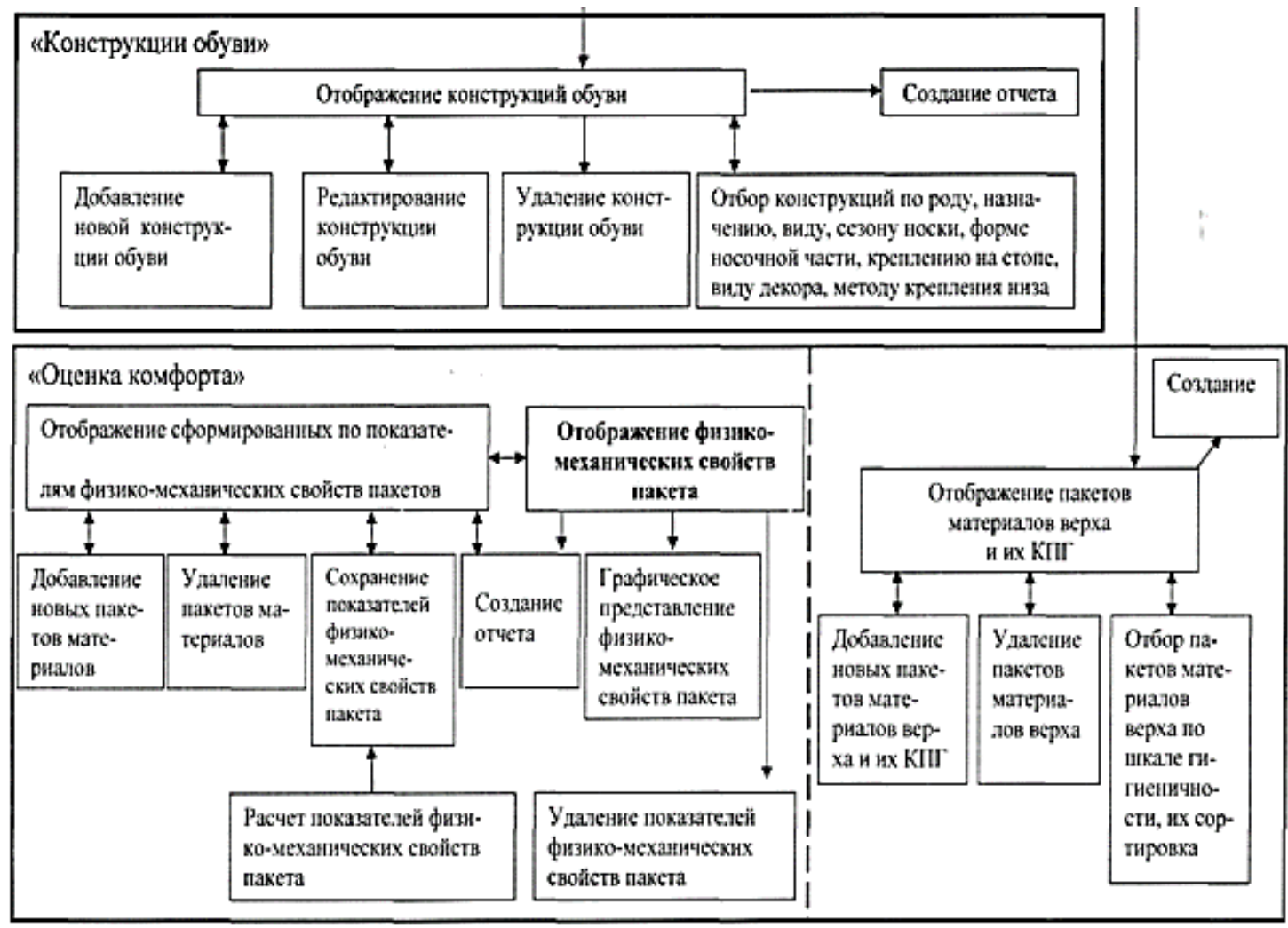

Рис. 9. - Схема работы программного обеспечения эмпирических показателей для оценки качества изделий.

Обратимся ко второй группе показателей. Очевидно, что такие показатели не дают оценки комплексной характеристике обуви (комфортности), которая интересует потребителя, большая часть которых устанавливается эмпирическим путём. Комфортность же зависит от многочисленных факторов, но наиболее существенными являются конструктивные характеристики моделей обуви и свойства применяемых материалов. Перспективу оценки качества обуви развития методов оценки качества обуви следует связывать с использованием САПР. Так, физико-механические свойства материалов обусловливают силовое взаимодействие стопы с обувью, обеспечивают защиту стопы от воздействия внешней среды и определяют её микроклимат. В такой постановке вопроса весьма привлекательно выглядит методика автоматизированной оценки комфортности обуви по показателям физико-механических свойств пакетов материалов верха, разработанная в РГУ им.А.Н.Косыгина.

Методика реализована в рамках комплекса, схема работы программного обеспечения которого показана на рис.9.

Следовательно, наряду с выделенными группами показателей, представляется целесообразным включить ещё одну группу «Комфортность», критериями которой, на наш взгляд, является температура и относительная влажность внутреннего пространства, давление верха обуви на стопу. Факторами, влияющими на величину давления обуви на стопу, является относительное удлинение, относительная влажность и жёсткость пакетов материалов, для которых нами установлены уровни варьирования и рациональные значения исходя из условий эксплуатации и производства изделий.

Созданная инструментальная система реализует методики автоматизированной оценки комфортности обуви и формирования наиболее рациональных пакетов верха по показателям физико-механических свойств материалов и экспресс-метод подбора конструкции обуви определённого уровня качества и назначения. Практическая значимость системы заключается в снижении субъективного фактора при выборе, сборе и упорядочении.

Специалисты по маркетингу сходятся во мнении, что потребители отдают свои главные предпочтения качеству продукции. Мониторинг рынка подтверждает устойчивые традиции спроса на качественные товары. Но не всё так просто и очевидно. 


\begin{tabular}{|c|c|c|c|c|c|c|}
\hline \multirow{4}{*}{ Impact Factor: } & ISRA (India) & $=3.117$ & SIS (USA) & $=0.912$ & ICV (Poland) & $=6.630$ \\
\hline & ISI (Dubai, UAE & $=0.829$ & РИНЦ (Russia) & $=0.156$ & PIF (India) & $=1.940$ \\
\hline & GIF (Australia) & $=0.564$ & ESJI (KZ) & $=8.716$ & IBI (India) & $=4.260$ \\
\hline & JIF & $=1.500$ & SJIF (Morocco & $=5.667$ & OAJI (USA) & $=0.350$ \\
\hline
\end{tabular}

Суть дела в том, что статистика - чистый оператор и статистические данные поэтому находятся в абсолютной зависимости от выбранного понятийного описания процесса. Статистические результаты всегда правильные, т.к. получаются путём использования проверенного математического аппарата, но правильность и истинность - «две большие разницы».

Чтобы «правильное» было «истинным», необходимо всю цепочку логических и математических действий выверить на правильность. Сертификация требуется не только вещественному и программному продукту. Сертифицированы должны быть и посылочные знания, иначе дефекты исходных суждений перекочуют в выводные знания. И никакая технология не исправит заложенного недостатка.

В идеологии производства, в особенности производства товаров непосредственного потребления, системообразующим фактором должно быть понятие «качества». Мы предвидим возражение: «что толку в качестве, если критерии качества ограничат количество и от приоритетности качественных характеристик пострадает ассортимент товаров, вырастет цена?», и у нас есть ответ оппонентам.

Если не будет обеспечено качество изделия, то никакое количество не поправит ситуации. Нужно будет либо согласиться с очевидным (для профессионалов) обманом потребителя, либо поступиться профессиональной компетенцией и сознательно пойти на понижение требований качества, допустив на рынок некачественный, по существу, товар. Что же касается ассортимента, то его зависимость от требований качества продукции относительно условна и опосредована. Ассортимент «завязан» на техническое состояние производства, технологию и профессионализм разработчиков.

Чем зримее черты цивилизованного рынка, тем актуальнее стоит вопрос качества. Более того, проблема качества из сферы теоретической актуальности перешла на уровень актуальности практической. Попробуем обосновать это смещение применительно к российской действительности.

Положительный сдвиг в сторону увеличения покупательной способности россиян за последние 5 лет бесспорен. Официальная статистика инфляции - явно лукавая, но, даже увеличив её на коэффициент 0,5 и получив реальные среднегодовые 15-20 \%, нам не останется ничего другого, как констатировать повышение благосостояния большинства сограждан в условиях определённого роста экономики в целом. Интенсивность динамики невелика, однако сам факт очевиден.
Вот только насколько справедливо говорить о «благосостоянии»? Деньги всего лишь меновой эквивалент. Заработав больше денег, вы совсем не обязательно заживете лучше. Деньги следует обменять на необходимые товары. И здесь уже в полный рост вырастает проблема качества. Заработав деньги, вы легко можете их истратить «незаметно», т.е. приобрести не товар, а «фантом товара».

«Фантом товара» - неспецифическое понятие для специальной системы знаний. Тем не менее, к нему необходимо привыкать как к теоретическому выражению реалий неразвитого товарного рынка.

Спекулируя на «белых» и «серых» «пятнах» идеологии качества, находящейся в крайне запущенном состоянии, «чёрные» производители некачественных товаров народного потребления вместе с сочувствующими чиновниками служб, отвечающими за качество изделий, наводнили рынок некондиционной продукцией.

Международная система контроля качества ИСО-9000 больше напоминает новейшее явление знаменитых потёмкинских деревень. Эффективно контролировать можно лишь то, что чётко прописано. Всякая недописанность - лаз для полулегального проникновения на поля охоты за потребителем.

ИСО-9000 целесообразно использовать не в качестве управленческого средства, а как инструмент профилактики нарушений качества. Круг, таким образом, замкнулся, ибо нарушение предполагает качество, а именно качество мы и не определили, как следует.

В системе специальных знаний, являющейся идеологией производства, «качество» подменяется «состоянием качества», которое в свою очередь сводится к количественным параметрам.

Количественным характеристикам придают дискретные выражения - так появляется ещё одно производное понятие. Только на этот раз не от коренного понятия «качество», а от его производного - от понятия «состояние качества».

Удивляет воинствующая активность стремления описать качество с помощью количества. Со времён Гегеля, утверждавшего, что качество - главное в определении явления, т.к. качество есть то, теряя что, оно перестаёт быть собою, минуло без малого двести лет. Пора было бы и усвоить простую истину: качество определяется не через количество, а через свойства. С помощью количественных измерений нам надо определять «меру» - «качественного» и «состояние качества» (уровень выраженности качества).

Заблуждения в теории практика редко когда исправляет, напротив, она их обычно скрывает до определённого момента развития. Дефекты 


\begin{tabular}{|c|c|c|c|c|c|c|}
\hline \multirow{4}{*}{ Impact Factor: } & ISRA (India) & $=3.117$ & SIS (USA) & $=0.912$ & ICV (Poland) & $=6.630$ \\
\hline & ISI (Dubai, UAE & $=0.829$ & РИНЦ (Russia & $=0.156$ & PIF (India) & $=1.940$ \\
\hline & GIF (Australia) & $=0.564$ & ESJI (KZ) & $=8.716$ & IBI (India) & $=4.260$ \\
\hline & JIF & $=1.500$ & SJIF (Morocco & $=5.667$ & OAJI (USA) & $=0.350$ \\
\hline
\end{tabular}

теории в грубом виде проявляются в сложных социально-экономических обстоятельствах, во время политической неопределённости.

Столь своеобразное время неслучайно «удобно» для расцвета теоретической неопределённости. Государство, запутавшись в многочисленных проблемах, отклоняется от контроля за экономическими процессами, рассчитывая на рынок, призванный расставить всё по своим местам. У рынка же свои законы функционирования. Рынок адаптирует теорию под собственные интересы: не подчиняется правилам, обоснованным теорией, а стремится подстроить эти правила под выгодный для него уклад отношений с потребителем.

Рекламное заявление: «покупатель всегда прав»- ложь! Всегда прав только законный порядок, определяющий характер отношений на рынке товаров. Сами же эти отношения строятся в зависимости от толкования качества товаров и соответствия качества цене, т.е. двух аспектов: теоретического и практического.

В теоретическом плане следует жёстко придерживаться фундаментального постулата: качество - это ассоциация свойств, характеризующих структурное и функциональное своеобразие не отдельно взятого явления, а некоторого множества явлений, объединённого общими законами образования и изменения, поэтому определять качество возможно только через наличие соответствующих свойств. Ввиду того, что из качественных свойств лишь эстетические (дизайн) оказываются доступными непосредственной оценке, требуется всесторонняя сертификация товара, точнее изделия, представленного для передачи на рынок.

Причём исследование изделия на качество, соответствующее интересам потребителя, не должно быть сведено к техническим и материаловедческим экспертизам. Требуется социальное, психологическое, медицинское и регионоведческое резюме.

Рассмотрим на примере обуви данное утверждение. Обувь, наряду с одеждой, относится к товарам, зависимым от национальных и исторических особенностей. Можно рекомендовать для реализации на рынке обувь, не учитывающую специфику географического, климатического и национального менталитета? Видимо, допустить такие изделия на рынок можно, но исключительно в ограниченном количестве, для разнообразия и расширения возможностей выбора потребителя.

Природа, питание, традиции сказываются на антропометрических особенностях населения: конфигурации и пропорциях стопы, голени и т.п. Обувь, разработанная без учёта национальных особенностей - анатомических, физиологических неизбежно будет способствовать развитию деформаций ноги. Обувь быстрее потеряет товарный вид, потребитель будет постоянно испытывать дискомфорт, который (принимая во внимание, что в среднем в России обувь носят, не считаясь с рекомендациями, пока физически не устареет) может сопровождаться обострением хронических заболеваний, либо приобретением их.

Уже сейчас Китай «выбросил» на рынок такое количество обуви, что всё население Земли $(\approx 6,5$ млрд человек) может быть обуто «а la Chine». Китайские производители руководствуются собственными интересами: создать в стране рабочие места и обеспечить сбыт продукции. Они предлагают обувь, сконструированную и сделанную без учёта национальной специфики стран-потребителей. Китайская обувь сегодня составляет серьёзную конкуренцию не только нашему отечественному производителю, но и таким странам законодателям обувной моды, как Италия, Франция, США, Чехия и т.п.

Вот уже пятый год подряд в секторе итальянского рынка обуви наблюдается значительное снижение объёмов производства. Активность данного сегмента внутреннего рынка снижается, а спрос на итальянскую продукцию на внешнем и внутреннем рынке низок. Учитывая превышение курса евро над долларом, конкуренция китайских товаров становится ещё более серьёзной на национальном итальянском рынке, особенно после отмены квот на продажу с 1 января 2004 г. Объёмы производства обуви снизились в 2005 г. на 9,7\% по сравнению с аналогичным периодом прошлого года. Что касается разницы в ценах, предложение продукции снизилось в абсолютных ценах примерно на 8,4 \%. В 2001-2004 гг. итальянское производство сократилось почти в полтора раза до 281 млн пар, что негативно отразилось на уровне занятости. Объём производства кожаной обуви снизился на 8,9\%, шлепанцев - на $23 \%$, резиновой обуви - на $32 \%$, парусиновой обуви на $40 \%$. Напротив, ежегодно Италия стабильно импортирует около 150 млн. китайской обуви. Итальянский производитель теряет свои позиции на международных рынках США, Германии и Франции. Рост курса евро по отношению к доллару, а также передел рынка в пользу азиатского производителя отрицательно сказываются на итальянском производителе. По данным Итальянской торговой палаты, более 600 компаний, включая производителей обуви, закрылись в период с 2005г. по 2017 г. Единственный сегмент рынка, в котором итальянские производители обуви удерживают ведущие позиции, - это производство для международных рынков элитной модельной обуви.

Так, в течение последних 10 лет число предприятий по производству обуви в Чехии 


\begin{tabular}{|c|c|c|c|c|c|c|}
\hline \multirow{4}{*}{ Impact Factor: } & ISRA (India) & $=3.117$ & SIS (USA) & $=0.912$ & ICV (Poland) & $=6.630$ \\
\hline & ISI (Dubai, UAE & $=0.829$ & РИНЦ (Russia & $=0.156$ & PIF (India) & $=1.940$ \\
\hline & GIF (Australia) & $=0.564$ & ESJI (KZ) & $=8.716$ & IBI (India) & $=4.260$ \\
\hline & JIF & $=1.500$ & SJIF (Morocco & $=5.667$ & OAJI (USA) & $=0.350$ \\
\hline
\end{tabular}

сократилось со 120 до 55. Но и это количество может уменьшиться в связи с отменой ограничений на импорт обуви из Китая. Если в конце XX в. чешские обувные фабрики производили около 70 млн. пар обуви, то в прошлом году это число составило приблизительно 5,5 млн. В 2016 г. в Чехию было импортировано около 50 млн пар обуви, из них 35 млн. - от китайских производителей. Средняя закупочная цена одной пары китайской обуви всего 54 кроны - стоимость, нереальная для чешских предприятий. «...Наши товары никто не покупает, потому что мы не в состоянии конкурировать азиатским товарам по стоимости, несмотря на то, что по качеству наша обувь намного лучше. К сожалению, чешский покупатель предпочитает более дешёвые товары, хотя и знает, что по времени они выдержат намного меньше, чем наша, качественная обувь»,- говорит член ассоциации обувной промышленности Чехии Лубомир Хлумский, фирма которого с 1998 г. занимается производством и продажей детской, женской и мужской обуви. В итоге, чешские производители теряют позиции на собственном рынке. Ситуацию осложняет то, что с 1 января 2005 г. Евросоюз по договоренности с Китаем и Всемирной торговой организацией отменил ограничения на ввоз китайской обуви. Вернуть их можно лишь в случае, если под угрозой окажется вся отрасль промышленности, причём в европейском масштабе.

Министр торговли США Карлос Гутьеррес в числе наиболее важных проблем отмечает необходимость принятия эффективных мер по сдерживанию сокращения рабочих мест в ряде отраслей американской промышленности, что также вызвано растущей конкуренцией китайских товаров в США.

Но нам ещё предстоит пройти путь, пройденный западными странамипроизводителями обуви. Вступление России в ВТО откроет рыночные границы для многих других желающих как можно быстрее сбыть некачественный товар. Более того, уже сегодня перед Россией, в отличие от западных соседей, стоит фатальная проблема экспансии «серого» импорта, возникшая ввиду несовершенства таможенного законодательства и стихийного развития «челночной торговли». Как заявил в одном из своих интервью полпред президента РФ в Сибирском федеральном округе Анатолий Квашнин, ежегодный объём «серого импорта китайских товаров» в Россию достигает 6 млрд долл. Но, даже в условиях цивилизованного рынка, допуск обуви на внутренний рынок без ограничения только на основе положительных заключений о качестве сырья, сопутствующих материалов, фурнитуры в существенных масштабах экспансии обувной продукции угрожает национальной безопасности России.

Особенности национального отношения к обуви поддаются количественной оценке. Изделия спокойно можно измерить на соответствие определённым требованиям, но надо иметь в виду, что само свойство оценивается только по формуле «есть или нет». Признав свойство существующим, эксперт вправе перейти к следующему этапу - к измерению интенсивности его существования, чтобы знать, насколько устойчиво и выражено данное свойство.

Отсутствие хотя бы одного из качественных свойств изделия, или недостаточность выраженности означают только одно - товаром изделие быть не должно. В исключительных случаях оно признается условно допущенным для реализации на национальном рынке.

Оккупация национального

рынка иностранными производителями обуви подрывает развитие соответствующей отрасли отечественной экономики, исторически адаптированной к специфике условий национального развития и особенностям антропометрических измерений.

Положение усугубляется тем, что Россия, получившая признание страны с рыночной экономикой, не вправе нарушать порядок во взаимоотношениях политических и рыночных структур. Односторонние действия государства в защите своих интересов могут быть квалифицированы как нарушение достигнутого статуса, вызвать экономические и прочие санкции мирового рынка. Вытеснение иностранного конкурента с национального рынка нужно проводить в соответствии с рекомендациями и традициями мирового сообщества.

Китайские, турецкие, отчасти восточноевропейские, производители обуви наводнили наш рынок и заняли на нем устойчивые позиции, благодаря покупательскому спросу на свою продукцию. [17-18]

Покупателя с ограниченными финансовыми возможностями привлекают цена, дизайн, рекламное сопровождение, ассортимент, заинтересованность продавца, культурный сервис. Не искушенный в профессиональных «секретах» потребитель о качестве судит по его внешнему проявлению и сервисной упаковке. Сам же сервис продажи умело переводит стрелки с качественных характеристик на внешне выигрышные свойства. Качество, как ассоциация важнейших свойств товара, «разрывается». Из всех свойств, образующих своим сочетанием качественную ассоциацию, выставляется только то свойство, которое выгодно продавцу, т.к. оно действительно представлению на соответствующем уровне потребительской заинтересованности. 


\begin{tabular}{|c|c|c|c|c|c|c|}
\hline \multirow{4}{*}{ Impact Factor: } & ISRA (India) & $=3.117$ & SIS (USA) & $=0.912$ & ICV (Poland) & $=6.630$ \\
\hline & ISI (Dubai, UAE & $=0.829$ & РИНЦ (Russia) & $=0.156$ & PIF (India) & $=1.940$ \\
\hline & GIF (Australia) & $=0.564$ & ESJI (KZ) & $=8.716$ & IBI (India) & $=4.260$ \\
\hline & JIF & $=1.500$ & SJIF (Morocco & $=5.667$ & OAJI (USA) & $=0.350$ \\
\hline
\end{tabular}

Секвестирование качества путём замены его упрощённым пониманием - наиболее распространённый рыночный приём. Неудовлетворительное состояние массовой потребительской культуры, устранённость контролирующих госструктур, их безынициативность, а где-то и прямая заинтересованность в сохранении сложившегося беспорядка позволяют манипулировать общественным сознанием, управлять поступками покупателей.

Оккупация российского рынка - явление, конечно же, временное, обусловленное экономической стагнацией, ограниченным платёжеспособным спросом основной массы населения, отсутствием эффективной и последовательной политики в сфере развития национального производства. Однако очевидная обусловленность ситуации не особенно утешает. В России любят шутить: нет ничего более постоянного, чем что-то временное. Чтобы временное явление не «застоялось», необходимо изменять условия, породившие его. Возможности имеются. Ранее всего надлежит разобраться в теории, которой руководствуются в практических действиях.

Недооценка теории закономерно ведёт к просчётам практики. В нашем случае такая недооценка, похоже, спланирована. Иначе, как объяснить, что при общепринятом определении качества через ассоциацию основных свойств предмета, от качественного критерия в нормативных документах остаются только «рожки да ножки», т.е. отдельные признаки.

В некоторой степени «виновата» в теоретической неопределённости, односторонности и сама теория качества. Качество естественных явлений отличается от качества искусственно созданных изделий. Естественные явления - природного происхождения, и все их свойства стихийные. Качество природных явлений не включает отношение их к человеческим потребностям. Грибы бессмысленно разделять по качеству на съедобные и ядовитые. Качество грибов в другом, и это другое определяет их место в биологической систематике. Деревья условно делят на красивые и некрасивые, ценные и сорные. К качеству подобное противоположение отношения не имеет. Искусственные изделия, напротив, характеризуются, прежде всего, соответствием нашим потребностям. Потребительские свойства входят в систему качества искусственных изделий, так же как и естественные. И не просто включаются, а по значимости опережают естественные.

Качество обуви обусловлено совокупностью потребительских характеристик. Не существенно в принципе, из какого материала обувь пошита.
Главное, чтобы свойства этого материала обеспечивали функциональную востребованность обуви потребителем.

Покупателю безразлично, при ценовом балансе, из натурального или искусственного материала изготовлена обувь. Ему важно, чтобы были гарантированы его требования к ней.

Отечественная же практика оценки качества обуви (и не только обуви) выворачивает теорию наизнанку, стремясь ориентироваться на естественные характеристики. Что-то российские идеологи качества будут делать, когда за них всерьёз возьмутся защитники прав животных, как случилось в Западной Европе, в частности в Великобритании.

Самое трагикомичное заключается в том, что природа сырья действительно не столь уж принципиальный вопрос, если развивать химическую и физическую технологии. Аналоги натурального сырья - реалии сегодняшнего производства и далеко уже не фантастика. Но злоключения качества отнюдь не ограничиваются проблемой сырья. Не менее актуальны и другие аспекты производства: учёт национальных, возрастных, природно-климатических особенностей при определении качества и условий допуска продукции на рынок.

К сожалению, на сегодня отечественный вклад в разработку политики, направленной на совершенствование качества обуви, а, по сути дела, на обеспечение прав потребителя, крайне невразумителен. Создаётся впечатление полной отвязанности стремлений производителей от интересов страны, давшей им гражданство.

Согласно теории предельной полезности и потребительского выбора, апробированной международной практикой, покупатель предпочитает товар, в наибольшей степени соответствующий его личному представлению о полезности в границах своих финансовых возможностей. Задача же государства создать необходимые законодательные предпосылки защиты интересов своих граждан и разработать надёжный механизм контроля.

При этом государство обязано понимать, что сознание потребителей, как правило, дилетантское. Потребителю не хватает профессиональной культуры для комплексной ориентации в условиях выбора варианта поведения. Поэтому государство либо те организации, которым делегировано право защиты, должны предоставить потребителям достаточный объём информации о потребительских свойствах товара.

Вместо этого покупателю предлагается, в лучшем случае, минимальный набор материаловедческих и технологических характеристик, что является грубым нарушением прав потребителя. Характеристика изделия должна включать в себя, наряду со статическими данными, подробные сведения динамического 


\begin{tabular}{|c|c|c|c|c|c|c|}
\hline \multirow{4}{*}{ Impact Factor: } & ISRA (India) & $=3.117$ & SIS (USA) & $=0.912$ & ICV (Poland) & $=6.630$ \\
\hline & ISI (Dubai, UAE & $=0.829$ & РИНЦ (Russia & $=0.156$ & PIF (India) & $=1.940$ \\
\hline & GIF (Australia) & $=0.564$ & ESJI (KZ) & $=8.716$ & IBI (India) & $=4.260$ \\
\hline & JIF & $=1.500$ & SJIF (Morocco & $=5.667$ & OAJI (USA) & $=0.350$ \\
\hline
\end{tabular}

(поведенческого) плана. К примеру, так описывать свойства товара, как это делают авторитетные фармацевтические предприятия, сообщая основные свойства, показания, противопоказания, возрастные рекомендации, функциональные предупреждения, способы употребления, условия хранения, рекомендованный срок эксплуатации.

Опыт использования такого подхода в других отраслях промышленности уже имеется. Уровень развития информационных технологий позволяет сегодня создавать целые коммуникативные системы сопровождения продукции, построенные на основе концепции CALS, широко используемой для повышения эффективности управления и сокращения затрат на информационное взаимодействие в процессах заказа, производства, поставок и эксплуатации товаров [2, 3]. Основой использования этой концепции является естественная потребность в организации «единого информационного пространства», обеспечивающего оперативный обмен данными между производителями и потребителями на всём протяжении «жизненного циикла» продукта: от маркетинга до утилизации.

Ничего такого в действиях, нацеленных на повышение качества продукции обувного производства, мы пока не видим. Нет даже стремления изменить информационную ситуацию, сложившуюся во времена, когда были ограничены ассортимент и количество товара. Для подтверждения сказанного обратимся к заключениям специалистов: «При сертификации серийно выпускаемой продукции экспертами ОС (органа по сертификации - прим. авт.) оценивается состояние производства непосредственно на предприятии или по представленным документам (заочно (!) - авт.) (техническое описание изделия конкретного вида, схема технологического процесса, материала, комплектующие изделия с санитарноэпидемиологические заключения на комплектующие материалы и обувь, которые подтверждают безопасность для здоровья потребителя, применяемых в обуви основных и вспомогательных материалов). В соответствии с программой, составленной экспертом при сертификации обуви в ИЛ (испытательной лаборатории - прим. авт.), определяются такие показания, как: прочность крепления подошвы; прочность крепления каблука; прочность ниточных швов заготовки верха обуви. При сертификации детской обуви дополнительно оцениваются конструкции заготовки верха обуви и гигиенические показатели применяемых материалов на соответствие нормам Сан ПиН № 42-125-4390-87». «Для работы в нижней части диапазона (цен - прим. авт.) предприятие должно выпускать такие модели обуви, которые являются доступными из-за невысокой цены и имеют в основном только базовый набор в соответствии с национальным стандартом».

Какие напрашиваются выводы? Во-первых, отрасль по-прежнему опирается на устаревшую позицию - самую простую и только необходимую: не навредить здоровью потребителя. Первую заповедь Гиппократа производители обуви и их контролеры усвоили крепко, но дальше не продвинулись. При таком раскладе осаду конкурентов долго сдерживать вряд ли удастся. Во-вторых, базовые свойства не следует отождествлять с качествами. Качествами свойства могут быть только в производственном цикле по причине его дифференциации на технологические операции. Но в этом случае качество целесообразно брать в кавычки, подчёркивая условность использования термина. В противном случае мы станем оперировать философскими и научными понятиями, что приведёт обязательно к искажению практических характеристик. Качество - это ассоциация определённых свойств, поэтому нельзя выдергивать образующие ассоциацию свойства по мере производственной надобности и выдавать их за качество. В-третьих, базовые свойства давно пора определять конвенционально, не ограничиваясь предложениями сангигиенистов и эпидемиологов. Немало ценного можно почерпнуть из исследований геронтологов, гериатров, регионоведов, валеологов, педиатров. В-четвёртых, до каких пор в базовых характеристиках будут практически отсутствовать эстетические свойства, пусть даже и в конспиративной форме.

Не совсем понятна и удовлетворённость фактической заменой Госстандартов на национальные стандарты. То, что в этом компоненте идеологии качества мы приняли международную терминологию, пользы не много. Вот если бы наши производственные и идеологические позиции сравнялись с европейскими, тогда бы можно было порадоваться. А так только усиливается хаос.

В отсутствие корпоративной культуры, традиций, отпущенные на «волю» фирмы займутся произволом. Госструктуры расписались в собственном бессилии управлять развитием рынка цивилизованно и вспомнили американскую сказку о том, что рынок сам всё устроит и упорядочит.

Неэффективность системы госконтроля за качеством - не в ё̈ статусе, а в функционировании. Нечистоплотность, не профессиональность чиновников не позволяют государственным структурам действовать полноценно. По официальным данным Федерального агентства по техническому регулированию и метрологии, в среднем за год имеется $2 \%$ отказов в сертификации. В то время 


\begin{tabular}{|c|c|c|c|c|c|c|}
\hline \multirow{4}{*}{ Impact Factor: } & ISRA (India) & $=3.117$ & SIS (USA) & $=0.912$ & ICV (Poland) & $=6.630$ \\
\hline & ISI (Dubai, UAE & $=0.829$ & РИНЦ (Russia & $=0.156$ & PIF (India) & $=1.940$ \\
\hline & GIF (Australia) & $=0.564$ & ESJI (KZ) & $=8.716$ & IBI (India) & $=4.260$ \\
\hline & JIF & $=1.500$ & SJIF (Morocco & $=5.667$ & OAJI (USA) & $=0.350$ \\
\hline
\end{tabular}

как более $30 \%$ продукции забраковывается непосредственно в торговле.

В Европейском союзе обязательной сертификации подлежит $\approx 4 \%$ ассортимента продукции не потому, что европейские чиновники либералы. Причина скрыта в порядках и традициях самого производства, цивилизованных отношениях на рынке, возраст которого превышает суммарно время династии Романовых и советской власти. Торопливость неизбежно влечет за собой издержки. Чтобы двигаться вместе со всеми общим строем, недостаточно одеться, обуться, как все, и встать в строй.

Пока власть и производители будут изображать рыночные отношения, расплачиваться придётся массовому потребителю, т.к. издержки лягут на его плечи. Эксклюзивные покупатели от перипетий российского рынка защищены действительно свободным выбором. Они приобретают товары непосредственно у авторитетных производителей. Чиновники готовы пойти на всё, чтобы оказаться среди эксклюзивных покупателей. Фирмы, вероятно, такого же мнения и готовы платить чиновникам за свободу собственных действий. Ситуацию иначе как ползучим государственным анархизмом не назовешь.

Согласно российским официальным предписаниям до последнего времени 70-80\% товарной номенклатуры требуют государственной сертификации качества. Критики отвергают такую практику и предлагают заимствовать западно-европейский опыт. Их не смущает, что доля нелегального и полулегального бизнеса в России оценивается в 40-60\%, т.е. уже сейчас при необходимости централизованно проверять на качество 70-80\% номенклатуры товаров, на рынке и так оказывается меньше $40 \%$ сертифицированного товара. Критики защищают интересы не понятно каких производителей. А кто встанет на защиту прав потребителей? Чиновники или, может быть, судьи, независимые только по определению. Остаются исключительно правозащитные общественные организации, которые сегодня есть, а завтра $-\mathrm{H}$

Мотивы улучшения качества прямо связаны с экономическими факторами. Это значит, что управление качеством имеет конечной целью достижение экономического эффекта, т.е. ориентировано на получение предприятием прибыли.

В современных условиях экономически успешная деятельность товаропроизводителя обеспечивается выпуском продукции, которая удовлетворяет следующим требованиям:

полностью соответствует запросам потребителей; отвечает требованиям безопасности и охраны окружающей среды; ТУ;

удовлетворяет действующим стандартам и

предлагается потребителю по

конкурентоспособным ценам;

является экономически выгодной для производства.

Управление конкурентоспособностью обуви на обувных предприятиях Южного федерального округа (ЮФО) связано с частой сменой ассортимента и усилением влияния региональных социально-экономических факторов.

Повышение конкурентоспособности обуви возможно только за счёт разработки новых моделей на основе маркетинговой информации и углубленного изучения предпочтений конкретных групп покупателей, ускорения процесса смены ассортимента при одновременном сохранении или повышении эффективности производственной системы.

Производители обуви на территории ЮФО занимают существенную часть отечественного выпуска обуви, а именно, более $30 \%$.

Несмотря на большую долю в производстве обуви в Южном федеральном округе спрос на обувь удовлетворён только на 19,6\%, остальное импортируется с ближнего или дальнего зарубежья. Зачастую такой импорт носит контрабандный характер. Именно ввоз дешевой обуви является наиболее серьёзной проблемой для отечественных обувных предприятий.

Также проблемой для предприятий ЮФО является недостаток качественного сырья и комплектующих для производства обуви, в результате чего продукция обувных фабрик Юга России проигрывает ценовую конкуренцию дешевой импортной обуви.

Кроме того, обувные компании ЮФО специализируются в основном только на мужской обуви. Причём изготовляют практически однотипные модели в одинаковой цветовой гамме. Конечно, трудозатраты на женскую и мужскую обувь несопоставимы. Поэтому женской обуви по ЮФО выпускается порядка $3 \%$, детской - $15 \%$, а спецобуви - 40 \%. Такой маленький объём выпуска женской обуви связан с тем, что на рынке женской обуви конкуренция намного острее, и в этом сегменте обувщики ЮФО сразу же сталкиваются с московско-китайскими производителями, которые сегодня «держат» большую часть рынка женской обуви. Но, к сожалению, обувщики не обращают внимания на то, что на рынке женской обуви отсутствует обувь для потребителей пожилого возраста, которой не занимаются китайские производители обуви, т.е. имеется ниша для производителей.

Более проблемной остаётся ситуация по выпуску большинством обувных предприятий 


\begin{tabular}{|c|c|c|c|c|c|c|}
\hline \multirow{4}{*}{ Impact Factor: } & ISRA (India) & $=3.117$ & SIS (USA) & $=0.912$ & ICV (Poland) & $=6.630$ \\
\hline & ISI (Dubai, UAE & $=0.829$ & РИНЦ (Russia & $=0.156$ & PIF (India) & $=1.940$ \\
\hline & GIF (Australia) & $=0.564$ & ESJI (KZ) & $=8.716$ & IBI (India) & $=4.260$ \\
\hline & JIF & $=1.500$ & SJIF (Morocco & $=5.667$ & OAJI (USA) & $=0.350$ \\
\hline
\end{tabular}

ЮФО детской обуви, что связано с отменой дотаций на её производство из Федерального бюджета; с несовершенством налогообложения детского ассортимента и отсутствием необходимого объёма и фасона колодок для её производства. На потребительском рынке ЮФО для детей отечественных производителей вытеснили зарубежные поставщики, которые могут позволить себе передать на реализацию обувь с условием оплаты после её фактической продажи. Однако данный товар, в большинстве своём, не имеет сертификатов соответствия и гигиенических сертификатов. Импортная обувь ввозится наиболее «ходовых», «усредненных» размеров и не предназначена для детей, поэтому на данный момент эту потребность дети и их родители вынуждены удовлетворять доступными по цене импортными изделиями взрослого ассортимента [19].

Обеспечение детей правильно подобранной, физиологически обоснованной обувью является одной из главных задач для отечественных производителей, в том числе для предприятий ЮФО.

Положение в ЮФО вызывает необходимость разработки комплекса мероприятий регионального значения, направленных на улучшение социально - экономической ситуации в ЮФО. Рост покупательской способности на качественную обувь в средне - ценовом потребительском сегменте определяют экономическую целесообразность проектирования предприятий обувной промышленности. Организация производства обуви в широком ассортименте позволит превратить дотационные сегодняшние регионы ЮФО в самоокупаемые, повысив уровень доходов населения; стимулирует создание новых рабочих мест; обеспечит развитие малого бизнеса и поддерживание

частнопредпринимательской легальной деятельности, части оборотов реального сектора экономики с целью формирования бюджета региона, т.к. реализация комплекса мероприятий регионального значения несёт в себе экономический, политический и социальный эффекты.

Основным этапом структурной перестройки должно стать повышение технического уровня производства на обувных предприятиях и конкурентоспособности продукции, обеспечение внедрения инновационной продукции, высоких технологий, замещение отдельных видов импортной обуви отечественной; выход её на российский и мировые рынки. Для этого необходимы мероприятия по модернизации и реконструкции уже существующих обувных производств и создание новых, усиления контроля и внедрения современных систем управления качеством; сертификация продукции и самих производств, развитие дилерской и товаропроводящей сети; проведение активной маркетинговой политики, расширение практики лизинговых схем инновационной деятельности.

Для возрождения производства детской обуви в ЮФО в первую очередь необходима организационная и финансовая поддержка обувным предприятиям на уровне правительства РФ, а также региональных и местных органов, а именно: [20]

в виде снижения НДС;

предоставления бессрочной ссуды;

срочной ссуды под льготный процент с отсрочкой платежей на 3 и более лет;

в виде поддержки обувных предприятий в обеспечении качественными и доступными по цене обувными материалами (натуральными, искусственными и текстильными).

Кроме того, следовало бы разрешить предприятиям направлять балансовую прибыль на пополнение оборотных средств для обеспечения их качественными и доступными по цене обувными материалами при выпуске детской обуви на условиях, предусмотренных для финансирования строительства, т.е. без обложения налогом. Возможны также госзаказ на детскую обувь с обеспечением авансирования.[21-22]

Местным органам необходимо дифференцированно подходить к установлению структуры и размеров местных налогов, т.е. снижать их величину при выпуске детской обуви. Особое внимание необходимо уделять созданию возможности приобретения обуви многодетным и малообеспеченным семьям за счёт целевых компенсаций, организации спецотделов, продаже по льготным ценам, в кредит и оплаты в рассрочку.

Как свидетельствует мировой опыт, лидерство в конкурентной борьбе добивается тот, кто наиболее компетентен в ассортиментной политике, в совершенстве владеет методами её реализации и может максимально эффективно ею управлять.

Прогноз тенденции развития ассортимента должен показывать такую траекторию развития процесса, которая позволяет обеспечить достижение намечаемого соответствия товарного предложения предприятием меняющейся в перспективе ассортиментной структуре спроса на рынке. Формирование на основе планирования ассортимента продукции - непрерывный процесс, продолжающийся в течение всего жизненного цикла продукции, начиная с момента зарождения замысла об её создании и кончая изъятием из товарной программы.

Для обеспечения конкурентоспособности продукции обувных предприятий ЮФО и СКФО с 


\begin{tabular}{|c|c|c|c|c|c|c|}
\hline \multirow{4}{*}{ Impact Factor: } & ISRA (India) & $=3.117$ & SIS (USA) & $=0.912$ & ICV (Poland) & $=6.630$ \\
\hline & ISI (Dubai, UAE & $=0.829$ & РИНЦ (Russia) & $=0.156$ & PIF (India) & $=1.940$ \\
\hline & GIF (Australia) & $=0.564$ & ESJI (KZ) & $=8.716$ & IBI (India) & $=4.260$ \\
\hline & JIF & $=1.500$ & SJIF (Morocco & $=5.667$ & OAJI (USA) & $=0.350$ \\
\hline
\end{tabular}

позиции её качества и востребованности, необходимо преобразование разрозненных предприятий лёгкой промышленности в этих регионах в динамичный конкурентоспособный обувной кластер.

Промышленный кластер - это группа географически соседствующих и интеграционно взаимодействующих компаний и связанных с ним организаций, функционирующих в определённой отраслевой (многоотраслевой) сфере и взаимодополняющих друг друга [20].

В ЮФО и СКФО имеются все необходимые условия для создания обувного кластера:

сохранились и функционируют учебные заведения, которые продолжают готовить высококвалифицированные кадры не только для обувных предприятий, но и для смежных отраслей, ещё живы традиции обувщиков, которые сложились в этих регионах, где и сегодня производится $35 \%$ от всей обуви, изготовленной в России в 2007 г.;

регионы ЮФО и СКФО характеризуются наличием большого количества незанятых людей (безработных), особенно велик процент безработных среди женщин, что требует создание новых рабочих мест, а это в свою очередь снизит социальную напряженность в этих регионах;

возможность выпуска обуви в широком ассортименте не только по видам, но и по методам крепления, в том числе и для детей, живущих в этих регионах, с учётом национальных особенностей;

географическая и транспортная близость к Западной Европе, где обувные компании находятся перед ещё более жёстким выбором: вынос производства в Китай, Индию, Тайвань либо в Восточную Европу. Как следствие существенные шансы на инвестиционное и технологическое партнёрство в рамках кластера с западноевропейскими производителями обуви;

позитивный опыт развития компании «Глория Джинс»: 12 фабрик, выпускающих ежегодно 20 млн. джинсовых изделий под марками Gloria Jeans и Gee Jay. Лидерство российской компании на рынке стран СНГ в нетрадиционном для российского легпрома нише - сегменте джинсовой одежды;

потенциал развития сырьевой базы за счёт реализации программы по развитию поголовья КРС и свиней;

наличие местных производителей некоторых видов комплектующих (подошва, каблук), в т.ч. соответствующих европейским стандартам [2324].

Создание обувного кластера в ЮФО обеспечит:

повышение эффективности и производительности предприятий, более чёткую координацию в работе; повышенное внимание к достижению целей бизнеса и удовлетворение ожиданий потребителей;

достижение и поддержание соответствия качества продукции и услуг предприятия установленным требования потребителей;

достижение удовлетворённости потребителей в том, что требуемое качество обеспечивается и поддерживается;

поддержание у имеющихся и потенциальных потребителей уверенности в возможностях предприятия;

открытие новых рыночных возможностей и сохранение завоеванных рынков сбыта;

сертификация и регистрация систем качества;

возможность соревноваться на этом поле с более крупными предприятиями (т.е. способность предлагать приемлемые цены или поддерживать их) [].

Действующие и вновь создаваемые предприятия и фирмы Юга России, используя предложенные мероприятия, смогут выпускать конкурентоспособную обувь в необходимом объёме для удовлетворения спроса различных групп населения с определённым уровнем доходов и социальной обеспеченности.

\section{Заключение}

Не существует ни одного предприятия, которое не имело бы внешнего окружения и не находилось бы с ним в состоянии постоянного взаимодействия. Любое предприятие нуждается в регулярном получении из внешней среды исходных продуктов для обеспечения своей жизнедеятельности. При этом каждое предприятие должно отдавать что-то во внешнюю среду в качестве компенсации за ее существование. Как только рвутся связи с внешней средой, предприятие погибает. В последнее время в связи с усилением и усложнением конкуренции, а также резким ускорением процессов изменения в окружающей среде предприятия всё в большей мере вынуждены уделять внимание вопросам взаимодействия с окружением развивать способности адаптации к изменениям внешней среды.

Ключевую роль в выработке и проведении политики взаимодействия предприятия с окружением играет менеджмент, особенно его верхний уровень. Вопросы долгосрочной стратегии взаимодействия предприятия со средой становятся во главу угла построения всех процессов управления. Менеджмент уже не занимается только внутренними вопросами предприятия. В равной, а может быть и в большей мере его взор направлен за пределы предприятия. Менеджмент старается строить эффективное 


\begin{tabular}{|c|c|c|c|c|c|c|}
\hline \multirow{4}{*}{ Impact Factor: } & ISRA (India) & $=3.117$ & SIS (USA) & $=0.912$ & ICV (Poland) & $=6.630$ \\
\hline & ISI (Dubai, UAE & $=0.829$ & РИНЦ (Russia) & $=0.156$ & PIF (India) & $=1.940$ \\
\hline & GIF (Australia) & $=0.564$ & ESJI (KZ) & $=8.716$ & IBI (India) & $=4.260$ \\
\hline & JIF & $=1.500$ & SJIF (Morocco & $=5.667$ & OAJI (USA) & $=0.350$ \\
\hline
\end{tabular}

взаимодействие предприятия с окружением не только путем воздействия на процессы, происходящие в предприятии, но и путем воздействия на окружающую среду.

Стратегическое управление, решающее эти задачи, выдвигается на первый план в комплексе процессов управления предприятием. Внешнее окружение предприятия, состояние взаимодействия с которым определяется преимущественно качеством управления им, можно представить в виде двух сфер.

Первая сфера - это общее внешнее окружение предприятия. Данное внешнее окружение отражает состояние общества, его экономики, природной среды и не связано непосредственно с конкретным предприятием. Общее внешнее окружение является более или менее одинаковым для подавляющего большинства предприятий.

Вторая сфера - это так называемое непосредственное деловое окружение предприятия. Это окружение формируют такие субъекты среды, которые непосредственно связаны или непосредственно воздействуют на деятельность данного конкретного предприятия. При этом важно подчеркнуть, что и предприятие в свою очередь может непосредственно влиять на них.

Общее внешнее окружение формируется под влиянием политических, правовых, социальнокультурных, экономических, технологических, национальных и международных процессов, а также процессов природопользования.

Непосредственное деловое окружение предприятия создают покупатели, поставщики, конкуренты, деловые партнеры, а также регулирующие службы и такие организации, как административные органы, деловые объединения и ассоциации, профсоюзы и т.п.

Управляя процессами взаимодействия предприятия с окружающей средой, менеджмент сталкивается с рядом серьезных проблем, порождаемых неопределенностью в состоянии окружающей среды. В связи с этим одной из сложнейших задач, стоящих перед менеджментом, является снижение неопределенности положения предприятия в окружении. Это достигается путем развития его адаптивности к внешней среде и установления широких связей с окружением, позволяющих предприятию органично вписываться в окружающую среду.

В зависимости от того, насколько предприятие адаптивно к изменениям в окружении, выделяется два типа управления предприятием: [25]

1) механистический тип управления; 2) органический тип управления.
Механистический тип управления предприятием характеризуется набором следующих характеристик:

- $\quad$ консервативная, негибкая структура;

- четко определенные, стандартизированные и устойчивые задачи;

- $\quad$ сопротивление изменениям;

- власть проистекает из иерархических уровней в организации и из позиции в организации;

- $\quad$ иерархическая система контроля;

• $\quad$ командный тип коммуникаций, идущих сверху вниз;

- содержанием коммуникаций преимущественно являются распоряжения, инструкции и принятые руководством решения.

Управлению предприятием органического типа характерно:

- $\quad$ гибкая структура;

- динамичные, не жестко определенные задачи;

- $\quad$ готовность к изменениям;

- $\quad$ власть базируется на знании и опыте;

- $\quad$ самоконтроль и контроль коллег;

- Много направленность коммуникаций (вертикальные, горизонтальные, диагональные и др.);

- $\quad$ содержанием коммуникаций являются информация и советы.

Каждый из данных типов имеет определенные преимущества.

Соответственно каждому из данных типов может быть дано определенное предпочтение в зависимости от характера окружения и уровня неопределенности. В том случае, если окружение динамично, если высок уровень неопределенности, более эффективным является органический тип управления предприятием. Если же окружение стабильно и неопределенность находится на низком уровне, предпочтение может быть отдано механистическому типу управления.

Развитие взглядов на управление: «одномерные» и «синтетические» учения.

Приступая к анализу развития учения об управлении, следует помнить о том, что основная задача управления - координация усилий всех элементов предприятия в деле осуществления успешности его функционирования.

Полезно обратить внимание на строение внутренней среды организации, выделяя такие элементы, как цели, кадры, задачи, технологию и структуру.

Надо помнить и о наличии внешней среды предприятия, четко понимая, что именно оно открывает доступ к ресурсам и, тем самым определяет возможность его существования. 


\begin{tabular}{|c|c|c|c|c|c|c|}
\hline \multirow{4}{*}{ Impact Factor: } & ISRA (India) & $=3.117$ & SIS (USA) & $=0.912$ & ICV (Poland) & $=6.630$ \\
\hline & ISI (Dubai, UAE & $=0.829$ & РИНЦ (Russia) & $=0.156$ & PIF (India) & $=1.940$ \\
\hline & GIF (Australia) & $=0.564$ & ESJI (KZ) & $=8.716$ & IBI (India) & $=4.260$ \\
\hline & JIF & $=1.500$ & SJIF (Morocco & $=5.667$ & OAJI (USA) & $=0.350$ \\
\hline
\end{tabular}

Другими словами, развитие мысли реально возможно только при наличии опыта еe реализации.

Практика управления также стара, как и предприятие. На глиняных табличках, датированных третьим тысячелетием до нашей эры, записаны сведения о коммерческих сделках и законах древней Шумерии.

Будем иметь в виду: Задача - это цель в конкретных условиях. Задача (задание) - это предписанная работа, серия работ или часть работы, которая должна быть выполнена заранее установленным способом в заранее оговоренные сроки. Задачи предписываются должности, а не работнику.

Взгляды на управление развивались по мере того, как развивались общественные отношения, совершенствовалась технология производства, появлялись новые средства связи и обработки информации. Однако управленческая мысль всегда знаменовала собой рубежи, начиная с которых происходили широкие преобразования в практику управления.

Управленческая мысль постоянно обращается к сфере самой коллективной деятельности или деятельности управления. Если в первой выделить субъектный и объектный планы, то получим три области внимания и поисков: задачи, люди и управленческая деятельность. Для начальной стадии развития науки об управлении было характерно акцентирование внимания на одной из них (одномерные учения), в последующем охват количества изучаемых факторов увеличивался (многомерные, синтетические учения). К настоящему времени эти две группы важнейших подходов, достаточно развиты и представляют совместно системно определившуюся науку об управлении. [26]

К числу наиболее заметных учений этой группы можно отнести: научное управление, бихевиористские учения и организационные теории.

Основателем и основным разработчиком идей научного управления является Фредерик Тейлор. Тейлор был инженером, поэтому для него было совершенно естественным (в пределах парадигмы своего времени) смотреть на управление человеком как на управление машиной. Базируясь на механистическом понимании сущности деятельности человека труда, его места в организации, Тейлор видел решение проблемы успешности предприятия в рационализации трудовых операций. Потому для него исходным было изучение задачи. При этом он полагал, что рабочие по своей натуре - ленивые и хорошо работать могут, в лучшем случае, при экономическом стимулировании. А потому - управленцы должны думать, а рабочие работать.

Основные принципы научного управления Тейлора состоят в следующем:

- разработка оптимальных приемов и методик осуществления работы на базе научного изучения затрат времени на отдельные операции;

- абсолютное следование научно обоснованным стандартам и нормам;

- подбор, обучение и расстановка рабочих на те рабочие места и задания, где они, реализуя свои способности, могут дать наибольшую отдачу;

- оплата по результатам труда (чем больше конкретный результат, тем больше оплата);

- использование функциональных администраторов, осуществляющих нормоконтроль по специализированным направлениям;

- поддерживание дружеских отношений между рабочими и менеджерами, с целью реализации научного управления.

В 20 - 30-е годы прошлого столетия обратили внимание на то, что производительность труда существенно зависит от социальных условий в организации, и может быть значительно увеличена, если в рабочих группах в процессе совместной деятельности создаются особые отношения - с признаками коллективизма. Перенос центра тяжести в управлении с задач на человека породил развитие различных бихевиористских теорий менеджмента.

Так, Вальтер Дилл Скотт выступал за то, что менеджеры должны смотреть не только сквозь призму их экономических интересов, но и социальных, признавая их заслуги. Мари Паркер Фоллет считала, что менеджер должен отказаться от формальных взаимодействий с рабочими, быть лидером, признанным рабочими, а не опирающимся на должностную власть. Ее трактовка менеджмента как «искусства добиваться результатов посредством действий других» во главу угла ставила гибкость и гармонию во взаимоотношениях между менеджерами и рабочими, исходя из ситуации, а не уповать на функциональные предписания.

Огромный вклад в развитие бихевиористского направления в управлении внес Абрахам Маслоу. Согласно учению Маслоу человек имеет сложную структуру иерархически расположенных потребностей, и управление в соответствии с этим должно вестись на основе выявления потребностей рабочего и использования соответствующих методов мотивирования.

Конкретное противопоставление научного направления и бихевиористских концепций в виде их теоретического обобщения нашло отражение в теориях «X» и «Y» Дугласа Мак Григора. Существуют два типа управления, отражающих в 


\begin{tabular}{|c|c|c|c|c|c|c|}
\hline \multirow{4}{*}{ Impact Factor: } & ISRA (India) & $=3.117$ & SIS (USA) & $=0.912$ & ICV (Poland) & $=6.630$ \\
\hline & ISI (Dubai, UAE & $=0.829$ & РИНЦ (Russia) & $=0.156$ & PIF (India) & $=1.940$ \\
\hline & GIF (Australia) & $=0.564$ & ESJI (KZ) & $=8.716$ & IBI (India) & $=4.260$ \\
\hline & JIF & $=1.500$ & SJIF (Morocco & $=5.667$ & OAJI (USA) & $=0.350$ \\
\hline
\end{tabular}

своей основе два диаметрально противоположных взгляда на работников.

Для предприятий типа «Х» характерны следуюшие кониептуальные предпосылки:

- обычный человек имеет унаследованную нелюбовь к работе;

- по причине нежелания работать только путем принуждения, с помощью приказов, контроля и угроз наказания можно человека побудить к тому, чтобы он осуществлял необходимые действия и затрачивал должные усилия, для достижения предприятием своих целей;

- $\quad$ средний человек предпочитает, чтобы им управляли, старается не брать на себя ответственности, имеет относительно низкие амбиции и желает находиться в безопасной ситуации.

Для предприятий типа «Y» характерны следуюшие предпосылки:

- выражение физических и эмоциональных усилий на работе для человека также естественно, как и во время игры или отдыха. Внешний контроль и угроза наказания не являются единственными средствами побуждения человека к деятельности. Человек в своей деятельности руководствуется определенным набором ценностей, усвоенными в процессе воспитания, осуществляя самоконтроль и само побуждение;

- ответственность и обязательства по отношению к целям организации зависят от вознаграждения, получаемого за результаты труда. Наиболее важным вознаграждением является то, которое связано с удовлетворением потребностей в самовыражении и само актуализации;

- обычный человек, воспитанный определенным образом, не только готов брать на себя ответственность, но и даже стремится к этому.

При этом МакГригор подчеркивал, что многим людям присуща готовность использовать свой опыт, знания и воображение в решении проблем предприятия. Однако современное индустриальное общество слабо использует интеллектуальный потенциал обычного человека.

Если, заботясь об успешности деятельности предприятия, Тейлор концентрировал внимание на том, как лучше выполнять задачи, исследуя операции и функции, Мэйо и бихевиористы искали ответы на те же вопросы, обращаясь к природе отношений в коллективе, к мотивам человеческой деятельности, то Фаоль пытался подойти к решению проблемы $c$ позиции совершенствования самой управленческой деятельности.

Анри Файоль почти всю свою сознательную жизнь (58 лет) проработал во французской компании по переработке угля и железной руды.
Он считал, опираясь на личный опыт, что при правильной организации своей работы каждый менеджер может добиться успеха.

Рассматривая предприятие как единый организм, Файоль полагал, что для любой деловой организации характерно наличие шести определенных видов деятельности, или функиий:

- техническая

деятельность

(производство);

- коммерческая деятельность (закупка, сбыт и обмен);

- финансовая деятельность (поиск и оптимальное использование капитала);

- деятельность безопасности (защита корпоративной собственности);

- эккаунтинг (деятельность по анализу, учету, статистике);

- управление (планирование, функция организации, распорядительство, координация и контроль).

Выделив управление в самостоятельный вид деятельности и наделив его пятью специфическими функциями (планирование, организация, распорядительство, координация и контроль), Файоль разработал четьрнадцать принщипов управления, которым он сам следовал в своей практике и от которых, как он считал, зависит успех управления:

- Разделение труда (повышает квалификацию и уровень выполнения работы).

- Власть (право отдавать команды и нести ответственность за результаты).

- Дисциплина (четкое и ясное взаимопонимание между рабочими и менеджерами, базирующееся на уважении к правилам и договоренностям, существующим на предприятии в основном - результат возможностей руководства).

- Единство распорядительства (распоряжения только от одного руководителя и подотчетность только одному руководителю).

- Единство руководства (один руководитель и единый план для каждого набора действий по достижению каких-то единых целей).

- Подчинение индивидуальных интересов общим интересам (менеджер должен добиваться с помощью личного примера и жесткого, но справедливого управления того, чтобы интересы индивидов, групп и подразделений не превалировали над интересами предприятия в целом).

- Вознаграждение персонала (оплата должна отражать состояние предприятия и стимулировать людей на работу с отдачей).

- Ц Централизация (уровень централизации и децентрализации должен зависеть от ситуации и 


\begin{tabular}{|c|c|c|c|c|c|c|}
\hline \multirow{4}{*}{ Impact Factor: } & ISRA (India) & $=3.117$ & SIS (USA) & $=0.912$ & ICV (Poland) & $=6.630$ \\
\hline & ISI (Dubai, UAE & $=0.829$ & РИНЦ (Russia) & $=0.156$ & PIF (India) & $=1.940$ \\
\hline & GIF (Australia) & $=0.564$ & ESJI (KZ) & $=8.716$ & IBI (India) & $=4.260$ \\
\hline & JIF & $=1.500$ & SJIF (Morocco & $=5.667$ & OAJI (USA) & $=0.350$ \\
\hline
\end{tabular}

выбираться таким образом, чтобы давать лучшие результаты).

- Цепи взаимодействия (четкое построение цепей следования команд от руководства к подчиненным).

- $\quad$ Порядок (все должны знать свое место на предприятии).

- Равенство (к рабочим следует подходить справедливо и по-доброму)

- Стабильность персонала (кадры должны находиться в стабильной ситуации).

- Инициатива (менеджеры должны поощрять подчиненных выдвигать идеи).

- Корпоративный дух (следует создавать дух единства и совместных действий, развивать бригадную форму работы).

Утверждая универсальность сформулированных принципов, Файоль тем не менее подчеркивал необходимость их гибкого применения, с учетом ситуации, в которой осуществляется управление.

Несомненно, огромный вклад в развитие управленческой мысли внес немецкий юрист и социолог Макс Вебер, разработавший теорию бюрократического построения предприятия и системы управления в частности.

Вебер считал, что бюрократическая система должна обеспечить работу предприятия как машины, гарантируя скорость, точность, порядок, определенность, непрерывность и предсказуемость.

Основными принципами построения предприятия, обеспечивающими эти качества, по Веберу, должны быть следующие:[27]

- разделение труда на базе функциональной специализации;

- хорошо определенная иерархическая система распределения власти;

- система правил и норм, определяющих права и обязанности работников;

- $\quad$ система правил и процедур поведения в конкретных ситуациях;

- отсутствие личностного начала в межличностных отношениях;

- прием на предприятие на основе компетентности и потребностей предприятия;

- продвижение по службе на основе компетентности и широких знаний предприятий, которые приходят с выслугой лет;

- стратегия к пожизненному найму;

- четкая система карьеры, обеспечивающая продвижение наверх для квалифицированных работников;

- управление административной деятельностью состоит в разработке и установлении доскональных письменных инструкций на предприятиях.

«Синтетические» учения об управлении
Для «синтетических» учений характерен взгляд на управление как на многоплановое, комплексное и изменяющееся явление, связанное множеством связей с внутренней и внешней средой предприятия. Первые успехи такого осмысления управления оформились как системный подход к предприятию. Открылась возможность глубокого проникновения в систему внутренних и внешних связей и многофакторного анализа, как объекта, так и субъекта управленческой деятельности.

Несомненно, одним из самых выдающихся теоретиков современности в области системного взгляда на управление следует считать Питера Дракера. Центром идей Дракера об управлении является систематизированное учение о менеджменте как о профессиональной деятельности и о менеджере как о профессии. Это позволило организовать изучение менеджмента в учебных заведениях и открыть подготовку менеджеров.

Одним из самых известных теоретических положений, выдвинутых Дракером, является его концепция управления по целям. Идея Дракера о том, что управление должно начинаться с выработки целей и потом переходить к формированию функций, системы взаимодействия и процесса, в корне перевернула логику управления.

Среди «синтетических» учений об управлении заметное место занимают ситуационные теории. Ситуационные теории дают рекомендации относительно того, как следует управлять в конкретных ситуациях. При этом рекомендуется пошаговый алгоритм решения проблем. Bo-первых, необходимо внимательно осуществить анализ конкретной ситуации, выделив какие требования к предприятию предъявляет ситуация и что характерно для ситуации. Bo-вmорых, должен быть выбран соответствующий подход к осуществлению управления. $\quad B$-третьих, управление должно создавать потенциал в предприятии и необходимую гибкость для того, чтобы можно было перейти к новому управленческому стилю, соответствующему ситуации. B-четвертых, управление должно произвести соответствующие изменения, позволяющие подстроиться к ситуации.

Одной из наиболее популярных системных концепций менеджмента является теория «7-S», разработанная в 80-е гг. (США). Было подмечено, что эффективная организация, как правило, формируется на базе семи взаимосвязанных составляющих, изменение каждой из которых с необходимостью требует соответствующего изменения остальных шести:

- стратегия - планы и направления действий, определяющие распределение ресурсов, 


\begin{tabular}{|c|c|c|c|c|c|c|}
\hline \multirow{4}{*}{ Impact Factor: } & ISRA (India) & $=3.117$ & SIS (USA) & $=0.912$ & ICV (Poland) & $=6.630$ \\
\hline & ISI (Dubai, UAE & $=0.829$ & РИНЦ (Russia) & $=0.156$ & PIF (India) & $=1.940$ \\
\hline & GIF (Australia) & $=0.564$ & ESJI (KZ) & $=8.716$ & IBI (India) & $=4.260$ \\
\hline & JIF & $=1.500$ & SJIF (Morocco & $=5.667$ & OAJI (USA) & $=0.350$ \\
\hline
\end{tabular}

фиксирующие обстоятельства по осуществлению определенных действий во времени для достижения поставленных целей;

- структура - внутренняя композиция предприятия, отражающая взаимное положение организационных подразделений, иерархическую субординацию этих подразделений и распределение власти между ними;

- cucтемы - процедуры и рутинные процессы, протекающие на предприятии;

- umam - ключевые группы персонала, существующие на предприяти и охарактеризованные по возрасту, полу, образованию и т.п.;

- cтиль - способ, каким руководители управляют предприятием, включая и организационную культуру;

- квалификация - отличительные возможности ключевых людей на предприятии;

- разделенные ценности - смысл и содержание основных направлений деятельности, которые предприятие доводит до своих членов.

В 1981 г. американец Ульям Оучи на основе японского опыта управления выдвинул теорию «Z», как бы дополняя и развивая идеи Мак Григора и нивелируя положения ситуационных теорий. Исходным пунктом концепции Оучи является положение о том, что человек - это основа любого предприятия и от него в первую очередь зависит успех функционирования предприятия. Исходя из этого, Оучи и сформулировал основные положения и правила эффективного управления людьми.

Идеи теории «Z» в сжатом виде сводятся к следующему:

- долгосрочный наем кадров;

- $\quad$ групповое принятие решений;

- индивидуальная ответственность;

- медленная дифференцированная оценка кадров и их умеренное пошаговое продвижение по службе;

- косвенный, неформальный контроль четкими и формализованными методами;

- неспециализированная карьера;

- всесторонняя забота о работниках.

Этот обзор учений об управлении показывает, что практика постоянно высвечивает все новые и новые проблемные грани управления совместной деятельностью, возникающие при поступательном ее развитии. Наука, в свою очередь, своевременно и эффективно отвечает на запросы практики, выдвигая при этом своего рода ориентиры, весьма полезные для практиков, так направляемые четырехступенчатую модель достижения успеха, а именно:

1. Решите, чего вы хотите (сформулируйте и поставьте перед собою цель).

2. Сделайте что-нибудь.
3. Посмотрите, что получится.

4. Если понадобится - меняйте подход, пока не добьетесь желаемого.

Ставить верные изели - это значит - уметь «правильно сформулировать результат».

Основные принцииь формирования и выбора своих иелей:

1. Выбирайте такие цели, которые заслуживают их достижения.

2. Выбирайте такую цель, которую сможете достичь своими силами.

3. Формулируйте свою цель в утвердительных терминах.

4. Выражайте свою цель точно, в сенсорных категориях.

5. Соотносите свою цель с контекстом (ситуацией).

6. Трезво оценивайте последствия достижения своей цели.

Подсознание играет важную роль во всем, что мы делаем. Деловые и организационные методы достижения целей (формализованные) обычно опускают этот фактор. То же относится и к индивидуальным целям, выбранным логическим, систематическим путем, «левым полушарием».

Думать в утвердительной форме - это приниип правильной формулировки результата.

С сожалением, обычно сосредотачиваются на попытках избежать нежелательного вместо того, чтобы думать о желаемом и добиваться желаемого. У них формируется «агрессивно-оборонительный», «отрицающий» характер вместо «утверждающего». «Отрицающий человек» переживает, в конце концов, тот сценарий, которого хотел бы избежать, ибо именно он закрепляется стратегически и реализуется. Можно назвать такую систему «избегания» осмотрительностью, реализмом, благоразумием и так далее. Наиболее действенно она проявляется при достижении внутренних целей, но когда дело касается осознаваемых целей «...?», она нередко приводит к непостижимым, на первый взгляд промахам. Потому первый принцип правильно сформулированного результата гласит: «Выражаю свою цель в утвердительных терминах».

Принципы сбалансированного самообновления

Возможно, мы начали понимать, что если мы хотим что-либо изменить, то начинать изменение надо с себя. И для того, чтобы изменить себя эффективно, мы, прежде всего, должны поменять свое восприятие.

Принципы НЛП (нейро-лингвистического программирования) предполагают учет всех четырех измерений. Это означает, что мы должны регулярно и последовательно развивать их самым разумным и сбалансированным образом. Расходование времени на самообновление требует от нас инициативы. 


\begin{tabular}{|c|c|c|c|c|c|c|}
\hline \multirow{4}{*}{ Impact Factor: } & ISRA (India) & $=3.117$ & SIS (USA) & $=0.912$ & ICV (Poland) & $=6.630$ \\
\hline & ISI (Dubai, UAE & $=0.829$ & РИНЦ (Russia) & $=0.156$ & PIF (India) & $=1.940$ \\
\hline & GIF (Australia) & $=0.564$ & ESJI (KZ) & $=8.716$ & IBI (India) & $=4.260$ \\
\hline & JIF & $=1.500$ & SJIF (Morocco & $=5.667$ & OAJI (USA) & $=0.350$ \\
\hline
\end{tabular}

Эффективные навыки - хорошо усвоенные принципь и модели поведения. Чтобы что-то в своей жизни превратить в навык, необходимы три компонента: Знание, Умение, Желание.

Знание - это теоретическая парадигма, определяющая что делать $u$ зачем. Умение определяет как делать. А желание - это мотивация делать.

Если однажды мы поверим, что отныне наме поведение зависит от наших решений, а не от окружающих условий, то самый первый навык, необходимый при начавшемся саморазвитии личности - это про активность. Под про активностью надо понимать, осмыслив ее как факт, что, инициируя происходящее, подчиняя чувства нашим ценностям, мы несем ответственность за свои действия (и, прежде всего, перед собой). Поведение проактивного человека есть продукт его собственного выбора, он не ищет «виноватых» за свои поступки и за их результаты. В этом случае он себя спрашивает, и в себе ищет ответ. Стивен Р. Кови полагает, что для достижения личной победы (победы над собой) человеку как минимум нужно еще два навыка (рис. 7.1) (кроме - «Будь проактивным» (1): это «Начинай, представляя конечную цель» (2), и «Сначала делай то, что необходимо делать сначала» (3). Если в значении цели в нашей деятельности мы уже достаточно четко определились, то с третьим навыком надо еще разобраться. В данном случае имеется в виду необходимость управлять своим временем, четко представляя степень важности и срочности тех дел, которые намечаем к исполнению [21].

Вполне очевидно, что для овладения навыком «Сначала делай то, что необходимо делать сначала», не срочные, но весьма важные дела по поддержанию своего ресурса будем стараться делать в первую очередь, и именно в этом деле как раз и будем нарабатывать первый и второй навык.

По мере овладения первыми тремя навыками мы все больше приобретем независимость от внешних факторов и все больше открываем возможность закрепить личную победу, пробуя по-новому взаимодействовать с окружающим нас миром себе подобных, осознавая объективную взаимозависимость. Для этого нам понадобятся еще три навыка: «Думай в духе выиграл/выиграл» (4), «Сначала стремись понять, а потом быть понятым» (5), «Достигайте синергии» (6). Сотрудничество и доверие - и результат и условие для закрепления этих важных в общении и коллективной деятельности навыков. Седьмой навык (7) Стивен Р. Кови назвал «Затачивай пилу». Он не двусмысленно полагал, что мы можем рассчитывать на успех, на эффективность только тогда, когда будем делать постоянные усилия в деле формирования всех названных навыков, работая над всесторонним саморазвитием.

Таким образом, надо признать, что, работая над своим обновлением в одиночку, сомнительно добиться успеха, даже имея все три составляющие для формирования необходимых навыков. Человек - существо социальное. Реально воспитание осуществляется только через поступок. В воспитании участвуют трое: кроме воспитуемого, еще должны быть воспитатель (делай как я) и ценитель (того чему учат и как получается). При самовоспитании - где взять еще двух недостающих? Выход только один - найти образ, который бы был учителем, найти образ, который был бы ценителем. Мы не оговорились, а вы не ошиблись - именно образ или образы. Для этого могут подойти литературные герои, друзья, подруги, папы, мамы, бабушки, дедушки ... при вашем богатом воображении.

Несмотря на принципиальные отличия вылерассмотренных этих концепций, они, тем не менее, имеют нечто общее в своей основе, что отражает определенную общность в мотивации человека к действиям.

Названные концепции Маслоу, Альдерфера, Мак Клеллакда, Герцберга позволяют сделать вывод о том, что отсугствует какое-либо канонизированное учение, объясняющее то, что лежит в основе мотивации человека и чем определяется мотивация. Каждая из изложенных теорий имеет определенное принципиальное отличие.

Таким образом, каждая из теорий имеет что-то особенное, отличительное, что дало ей возможность получить широкое признание теоретиков и практиков и внести существенный вклад в разработку знаний о мотивации. Однако при этом, несмотря на принципиальные различия, все четыре вышеописанные теории имеют нечто общее, позволяющее установить определенные параллели между ними. Характерной особенностью всех четырех теорий является то, что они изучают потребности и дают классификацию потребностей, позволяющую делать некие выводы о механизме мотивации человека. Сравнивая классификации всех четырех теорий, можно отметить, что выделенные в различных теориях группы потребностей достаточно определенно соответствуют друг другу.

Многое зависит от организационной культуры и управления коллективом предприятий легкой промышленности.

Предприятие - это сложный организм, основой жизненного потенциала которого является организационная культура: то, ради чего люди стали членами предприятия; то, как строятся отношения между ними; какие устойчивые нормы 


\begin{tabular}{|c|c|c|c|c|c|c|}
\hline \multirow{4}{*}{ Impact Factor: } & ISRA (India) & $=3.117$ & SIS (USA) & $=0.912$ & ICV (Poland) & $=6.630$ \\
\hline & ISI (Dubai, UAE & $=0.829$ & РИНЦ (Russia & $=0.156$ & PIF (India) & $=1.940$ \\
\hline & GIF (Australia) & $=0.564$ & ESJI (KZ) & $=8.716$ & IBI (India) & $=4.260$ \\
\hline & JIF & $=1.500$ & SJIF (Morocco & $=5.667$ & OAJI (USA) & $=0.350$ \\
\hline
\end{tabular}

и принципы жизни и деятельности предприятия они разделяют; что, по их мнению, хорошо, а что плохо, и многое другое из того, что относится к ценностям и нормам. Все это не только отличает одну организацию от другой, но и существенно предопределяет успех функционирования и выживания предприятия в долгосрочной перспективе. Организационная культура не так явно проявляется на поверхности, ее трудно «пощупать». Если можно говорить о том, что предприятие имеет «душу», то этой душой является организационная культура.

Носителями организационной культуры являются люди. Однако на предприятиях с устоявшейся организационной культурой они как бы отделяются от людей и становятся атрибутом предприятия, его частью, оказывающей активное воздействие на членов предприятия, модифицирующей их поведение в соответствии с теми нормами и ценностями, которые составляют его основу.

Так как культура играет очень важную роль в жизни предприятия, то оно должна являться предметом пристального внимания со стороны руководства. Управление не только соответствует организационной культуре и сильно зависит от нее, но и может в свою очередь оказывать влияние на формирование и развитие организационной культуры. Для этого менеджеры должны уметь анализировать организационную культуру и оказывать влияние на ее формирование и изменение в желательном направлении.

Понятие и структура организационной культурь

В современной литературе существуют как очень узкие, так и очень широкие толкования того, что же представляет собой культура предприятия.

Чаще всего организационная культура трактуется как принимаемые большей частью предприятия философия и идеология управления, предположения, ценностные ориентации, верования, ожидания, расположения и нормы, лежащие в основе отношений и взаимодействий как внутри предприятия, так и за его пределами.

Используя то общее, что присуще многим определениям, можно понимать организационную культуру следующим образом. Организационная культура - это набор наиболее важных предположений, принимаемьх коллективом предприятия и получающих выражение в заявляемых предприятием иенностях, задающих людям ориентиры их поведения и действий. Эти ценностные ориентации передаются индивидам через «символические» средства духовного и материального внутриорганизационного окружения.

Базовые предположения это то, чего придерживается коллектив предприятия в своем поведении и действиях. Эти предположения часто связаны с видением окружающей индивида среды (группы, предприятия общества, мира) и регулирующих еe переменных (природа, пространство, время, работа, отношения и т. д.). Нередко бывает трудно сформулировать это видение применительно к предприятию.

Ценности (или ценностные ориентации) ориентируют индивида в том, какое поведение следует считать допустимым или недопустимым. Так, на некоторых предприятиях считается, что «клиент всегда прав», поэтому в них недопустимо обвинять клиента за неудачу в работе коллектива предприятия. В других - может быть все наоборот. Однако и в том, и в другом случае принятая ценность помогает индивиду понять то, как он должен действовать в конкретной ситуации.

«Символика» это то, посредством чего ценностные ориентации «передаются» коллективу предприятия. Многие предприятия имеют специальные, предназначенные для всех документы, в которых они детально описывают свои ценностные ориентации. Однако содержание и значение последних наиболее полно раскрываются работникам через «ходячие» истории, легенды и мифы. Их рассказывают, пересказывают, толкуют. В результате этого они оказывают иногда больше влияния на индивидов, чем те ценности, которые записаны в рекламном буклете предприятия.

Организационная культура имеет определенную структуру. Последнюю можно рассматривать как трехуровневую.

Первый, «поверхностный», или «символический» уровень. Включает такие видимые внешние факты, как - применяемая технология и архитектура, использование пространства и времени, наблюдаемое поведение, язык, лозунги и т.П., или все то, что можно ощущать и воспринимать через известные пять чувств человека (видеть, слышать, ощущать вкус и запах, осязать). На этом уровне вещи и явления легко обнаружить, но не всегда их можно расшифровать и интерпретировать в терминах организационной культуры.

Второй, «подповерхностный» уровень. На этом уровне обнаруживаются ценности и верования, разделяемые коллективом предприятия, в соответствии с тем, насколько эти ценности отражаются в символах и языке. Восприятие ценностей и верований носит сознательный характер и зависит от желания людей.

Третий, «глубинный» уровень. Включает базовые предположения, которые трудно осознать даже самим коллективом предприятия без специального сосредоточения на этом вопросе. Эти скрытые и принимаемые на веру предположения направляют поведение людей, 


\begin{tabular}{|c|c|c|c|c|c|c|}
\hline \multirow{4}{*}{ Impact Factor: } & ISRA (India) & $=3.117$ & SIS (USA) & $=0.912$ & ICV (Poland) & $=6.630$ \\
\hline & ISI (Dubai, UAE & $=0.829$ & РИНЦ (Russia & $=0.156$ & PIF (India) & $=1.940$ \\
\hline & GIF (Australia) & $=0.564$ & ESJI (KZ) & $=8.716$ & IBI (India) & $=4.260$ \\
\hline & JIF & $=1.500$ & SJIF (Morocco & $=5.667$ & OAJI (USA) & $=0.350$ \\
\hline
\end{tabular}

помогая им воспринять атрибуты, характеризующие организационную культуру.

Соответственно тому, какие из указанных уровней изучаются, существует деление организационных культур на субъективные и объективные.

Субъективная организационная культура исходит из разделяемых работниками образцов предположений, веры и ожиданий, а также из группового восприятия организационного окружения с его ценностями, нормами и ролями, существующими вне личности. Сюда включают ряд элементов «символики», особенно ее «духовной» части: герои предприятия, мифы, истории о предприятии и его лидерах, организационные табу, обряды и ритуалы, восприятие языка общения и лозунгов. Субъективная организационная культура служит основой формирования управленческой культуры, т.е. стилей руководства и решения руководителями проблем, их поведения в целом. Это создает различие между схожими на вид организационными культурами. Например, два предприятия могут заявлять о качественном обслуживании своих клиентов. Но конечный результат будет во многом зависеть от того, как будет осуществляться руководство этим процессом.

Объективную организационную культуру обычно связывают с физическим окружением, создаваемым на предприятии: само здание и его дизайн, места расположения, оборудование и мебель, цвета и объем пространства, удобства, кафетерий, комнаты приема, стоянки для автомобилей и сами автомобили. Все это в той или иной степени отражает ценности, которых придерживается коллектив предприятия. Хотя оба аспекта организационной культуры важны, однако субъективный аспект создает больше возможностей для нахождения как общего, так и различий между людьми и между предприятиями.

Содержание организационной культуры

Конкретную организационную культуру можно рассматривать на основе десяти характеристик:

- осознание себя и своего места на предприятии (одни культуры ценят сокрытие работником своих внутренних настроений, другие - поощряют их внешнее проявление; в одних случаях независимость и творчество проявляется через сотрудничество, а в других - через индивидуализм);

- коммуникационная система и язык общения (использование устной, письменной, невербальной коммуникации, «телефонного права» и открытости коммуникации разнится от группы к группе, от предприятия к предприятию; жаргон, аббревиатуры, жестикуляции варьируются в зависимости от отраслевой, функциональной и территориальной принадлежности предприятий);

- внешний вид, одежда и представление себя на работе (разнообразие униформ и спецодежды, деловых стилей, опрятность, косметика, прическа и т.п. подтверждают наличие множества микрокультур);

- что и как едят люди, привычки и традиции в этой области (организация питания работников, включая наличие или отсутствие таковых мест на предприятии; люди приносят с собой еду или посещают кафетерий внутри или вне предприятия; дотация питания; периодичность и продолжительность питания; едят ли работники разных уровней вместе или отдельно и т.п.);

- осознание времени, отношение к нему и его использование (степень точности и относительности времени у работников; соблюдение временного распорядка и поощрение за это; моно хроническое или полихроническое использование времени);

- взаимоотношения между людьми (по возрасту и полу, статусу и власти, мудрости и интеллекту, опыту и знаниям, рангу и протоколу, религии и гражданству и т.п.; степень формализации отношений, получаемой поддержки, пути разрешения конфликтов);

- ценности (как набор ориентиров в том, что такое хорошо и что такое плохо) и нормы (как набор предположений и ожиданий в отношении определенного типа поведения) - что люди ценят в своей организационной жизни (свое положение, титулы или саму работу и т.п.) и как эти ценности сохраняются;

- вера во что-то и отношение или расположение к чему-то (вера в руководство, успех, в свои силы, во взаимопомощь, в этичное поведение, в справедливость и т.п.; отношение к коллегам, клиентам и конкурентам, к злу и насилию, агрессии и т.п.; влияние религии и морали);

- процесс развития работника и научение (бездумное или осознанное выполнение работы; полагаются на интеллект или силу; процедуры информирования работников; признание или отказ от примата логики в рассуждениях и действиях; абстракция и концептуализация в мышлении или заучивание; подходы к объяснению причин);

- трудовая этика и мотивирование (отношение к работе и ответственность по работе; разделение и замещение работы; чистота рабочего места; качество работы; привычки по работе; оценка работы и вознаграждение; отношения «человек - машина»; индивидуальная или групповая работа; продвижение по работе). 


\begin{tabular}{|c|c|c|c|c|c|c|}
\hline \multirow{4}{*}{ Impact Factor: } & ISRA (India) & $=3.117$ & SIS (USA) & $=0.912$ & ICV (Poland) & $=6.630$ \\
\hline & ISI (Dubai, UAE & $=0.829$ & РИНЦ (Russia) & $=0.156$ & PIF (India) & $=1.940$ \\
\hline & GIF (Australia) & $=0.564$ & ESJI (KZ) & $=8.716$ & IBI (India) & $=4.260$ \\
\hline & JIF & $=1.500$ & SJIF (Morocco & $=5.667$ & OAJI (USA) & $=0.350$ \\
\hline
\end{tabular}

Выше отмеченные характеристики культуры предприятия, взятые вместе, отражают и придают смысл концепции организационной культуры.

Члены предприятия, разделяя веру и ожидания, создают свое физическое окружение, вырабатывают язык общения, совершают адекватно воспринимаемые другими действия и проявляют понимаемые всеми чувства и эмоции. Bce это, будучи воспринятым работниками, помогает им понять и интерпретировать культуру предприятия, т.е. придать свое значение событиям и действиям и сделать осмысленным свое рабочее окружение. Поведение людей и групп внутри коллектива предприятия сильно связано нормами, вытекающими из этих разделяемых верований, ожиданий и действий.

Содержание организационной культуры влияет на направленность поведения и определяется не простой суммой предположений, а тем, как они связаны между собой и как они формируют определенные образцы поведения. Отличительной чертой той или иной культуры является относительный порядок, в котором располагаются формирующие еe базовые предположения, что указывает на то, какая политика и какие принципы должны превалировать в случае возникновения конфликта между разными наборами предположений планированию карьеры.

\section{References:}

1. Rebrin, Y. I. (2014). quality Management: textbook. (p.204). Taganrog, Publisher TSURE.

2. (2007). GOST 14918-80. Galvanized sheet steel with continuous lines. Technical conditions. Enter. 1981-30-06. [as amended on October 18, 2016]. (p.8). Moscow: publishing house of standards.

3. (2004). GOST 52246-2016. Hot-dip galvanized sheet metal. Technical conditions. - Enter. 201601-01. (p.16). Moscow: publishing house of standards.

4. (2004). 52146-2003, GOST. Cold-rolled and cold-rolled hot-dip galvanized sheet with polymer coating with continuous lines. Technical conditions. - Enter. 2004-07-01. (p.10). Moscow: publishing house of standards.

5. (2016). GOST 19904 - 90. Cold-rolled sheet metal. Assortment. - Enter. 1991-01-01. [in the edition of October 18, 2016]. (p.4). Moscow: publishing house of standards.

6. (2016). GOST 7566-94. Metal products. Acceptance, marking, packaging, transportation and storage. - Enter. 1998-01-01. [as amended on October 18, 2016]. (p.14). Moscow: publishing house of standards.

7. (2013). GOST 26877-2008. Metal rolling. Methods of measuring shape deviations. - Enter. 2013-01-01. (p.12). Moscow: publishing house of standards.

8. (1999). SP 53-101-98. Production and quality control of steel building structures. - Enter. 1999-01-01. (p.40). Moscow: Gosstroy of Russia, GUP tspp.
9. (2013). GOST 23118-2012. Steel construction structures. General specifications. - Enter. 201307-01. (p.20). Moscow: STANDARTINFORM.

10.(2013). SP 70.13330.2012 Bearing and enclosing structures. The updated edition of SNiP 3.03.01-87 (with Change N 1). - Enter. 2013-07-01. (p.120). Moscow: Gosstroy, the FAA "DSF".

11. (2010). SP 48.13330.2011. Organization of construction. The updated edition of SNiP 1201-2004 (with Change N 1).- Enter. 2011-05-20. (p.15). Moscow: The Ministry Of Regional Development.

12. (2003). GOST 30245-2003 steel bent closed welded square and rectangular profiles For building structures. Technical conditions. Enter. 2003-30-09. (p.16). Moscow: publishing house of standards.

13. (2016). GOST 19903-2015. Hot-rolled sheet metal. Assortment. - Enter. 2016-09-01. (p.20). Moscow: STANDARTINFORM.

14. (2015). GOST 27772-2015. Rolled products for structural steel constructions. General specifications. - Enter. 01.09.2016. (p.19). Moscow: STANDARTINFORM.

15. (2016). GOST 9.401-91. Unified system of protection against corrosion and aging of materials and products. General requirements and methods of accelerated tests for resistance to climatic factors. - Enter. 1992-30-06. (p.5). Moscow: publishing house of standards.

16. Prokhorov, V. T., et al. (2014). The quality revolution: through the ad or through a quality real. monograph under the General editorship of doctor of technical Sciences, Professor V. T. 


\begin{tabular}{|c|c|c|c|c|c|c|}
\hline \multirow{4}{*}{ Impact Factor: } & ISRA (India) & $=3.117$ & SIS (USA) & $=0.912$ & ICV (Poland) & $=6.630$ \\
\hline & ISI (Dubai, UAE & $=0.829$ & РИНЦ (Russia & $=0.156$ & PIF (India) & $=1.940$ \\
\hline & GIF (Australia) & $=0.564$ & ESJI (KZ) & $=8.716$ & IBI (India) & $=4.260$ \\
\hline & JIF & $=1.500$ & SJIF (Morocco & $=5.667$ & OAJI (USA) & $=0.350$ \\
\hline
\end{tabular}

Prokhorov (Eds.). VoIP (branch) of DSTU. (p.384). Novocherkassk: URGU (NPI).

17. Balandyuk, N. M., et al. (2012). The restructuring of enterprises as one of the most effective forms of improving the competitiveness of enterprises on markets with unstable demand: monograph/ under the General editorship of doctor of technical Sciences, Professor V. T. Prokhorov (Eds.). FGBOU VPO "South-ROS. state University of Economics and service". (p.347). Mines: FGBOU VPO yurgues.

18. Walnut, L. H., et al. (2012). The impact of cash flow on the efficiency of the cluster formed on the basis of the Shoe enterprises of the southern Federal district and skfol under the General editorship of doctor of technical Sciences, Professor V. T. Prokhorov (Eds.). (p.354). Mines: FGBOU VPO yurgues.

19. Prokhorov, T. V., Aspen, T. M., \& Walnut, L. G. (2012). Innovative technological processes in light industry for the production of competitive and popular products: monograph / under the General editorship of doctor of technical Sciences, Professor V. T. Prokhorov (Eds.). VoIP (branch) of DSTU. (p.435). Mines: Isoip (branch) DSTU.

20. Kolesnikov, S., et al. (2015). High-tech technologies in the service of human ecology [monograph],- Under the General editorial prof. Chernovoy I. V. (Eds.). materials of II International scientific-technical conference "high technologies in the service of human ecology, VoIP (branch) of DSTU in Shakhty. (p.144). Novocherkassk: Lik.

21. Prokhorov, V. T., et al. (2015). Assortment and assortment policy. monograph / under the General ed. Dr. Techn. Sciences, Professor V. T. Prokhorov (Eds.). VoIP (branch) of DSTU. (p.246). Novocherkassk: URGU (NPI).

22. Prokhorov, V. T., et al. (2015). About new opportunities of regions of SFD and skfo on formation of preferences by consumers of the production made at the enterprises of light industry: the monograph. on the General edition of doctor of technical Sciences, prof. V. T. Prokhorov (Eds.). In the sphere of service and business (Phil.) Fader. state budget. educated. institutions higher. professional education "don state technical. UN-t " in the Mine Growth. region. (Isoip (branch) DGTU). (p.316). Novocherkassk: URGU (NPI).

23. Prokhorov, V. T., et al. (2017). The concept of import substitution of products of light industry: background, challenges, and innovations. monograph / under the General editorship of Dr. sci. prof. V. T. Prokhorova (Eds.). Institute of service sector and entrepreneurship (branch) of don state technical University. (p.334). Mines: Isoip (branch) DSTU.

24. Surovtseva, O. A., et al. (2018). Management of the real quality of products rather than advertising by motivating the behavior of the leader of the team of the enterprise of the industry. monograph by prof. V. T. Prokhorova; Institute of service sector and entrepreneurship (branch) of don state technical University. (p.384). Novocherkassk: URGU (NPI).

25.Zaitseva, D. R., \& Kushnareva, I. V. (2017). "Classification of quality costs" international scientific and practical conference. Tools and mechanisms of formation of competitive state and regional economy. Isop (branch) of DSTU in Shakhty.

26. Zaitseva, D. R., Prokhorov, V. T., Bordukh, D. O., Kozachenko, P. N., \& Tikhonova, N. In. (2017). "On the role of motivation of a person-a leader for managing the company's team and actions to ensure the full implementation of manufactured products to manufacturers" Technologies, design, science, education in the context of inclusion. Collection of proceedings. Isop (branch) of DSTU in Shakhty.

27. (2017). GOST R 57189-2016/ISO/TS 9002:2016 "quality management System with guidance for use ISO 9001:2015" (ISO/TS 9002:2016, IDT). 2017-11-01. (p.35). Moscow: publishing house of standards. 